\title{
HISTÓRIA DO CONCEITO DE HUMANITAS: DA MITOPOÉTICA A ALLEGORESIS ESTOICA *
}

History of the concept of humanitas: from mythopoetics to stoic allegoresis

Cleber Ranieri Ribas de Almeida **

Resumo: Neste artigo proponho-me reconstituir a trajetória etimológica, filológica e experiencial do conceito de humanitas desde sua origem estoica no Círculo Cipiônico até sua assimilação pela tradição imperial panegírica augustana. $O$ propósito é compreender porque, desde a origem, tal conceito apresenta um núcleo semântico de significação inconstante, volátil e aberto. Tal indeterminação semântica, como tentarei provar, adveio do progressivo processo de degeneração das representações mitopoéticas do homem em favor de uma compreensão noética. Posteriormente, esta compreensão noética fora assimilada pelo gênio estoico-romano na forma de uma representação alegórica (allegoresis) cujo conteúdo semântico tornara-se meramente linguístico e autorreferente. Os símbolos da experiência foram assim reduzidos a meros jogos de linguagem. Nesta lógica, a compreensão do conceito de humanitas em sua origem depende menos de uma investigação acerca das evidências filológicas quanto ao uso da palavra nos textos canônicos e mais de uma investigação acerca das experiências que possibilitaram a formação de uma consciência da unidade simbólica da humanidade enquanto grandeza política de referência.

Palavras-chave: Humanitas. Humanismo. Círculo Cipiônico. Mos Maiorum. Estoicismo.

Abstract: This paper aims to reconstruct the etymological, philological and experiential trajectory of the concept of humanitas from its Stoic origin in the Scipionic Circle to its assimilation by the Augustinian imperial tradition (especially

\footnotetext{
* Artigo recebido em 31/03/2020 e aprovado para publicação em 23/09/2020.

** Doutor em Filosofia pela Universidade de São Paulo (USP). Professor do curso de Bacharelado em Ciência Política da Universidade Federal do Piauí (UFPI).
} 
in panegyric texts). My purpose is to understand why, from the beginning, such a concept has presented a semantic core whose meaning is inconstant, volatile and open. I will try to prove that this semantic indeterminacy comes from the progressive degeneration process of the mythopoetic representations of man in favor of a noetic understanding. This noetic understanding was later assimilated by the Roman Stoicism in the form of an allegorical representation (allegoresis) whose semantic content had become merely linguistic and self-referential. The symbols of experience were thus reduced to mere language games. Accordingly, the understanding of the original concept of humanitas depends less on an investigation about the philological evidence regarding the use of the word in canonical texts and more on an investigation about the experiences that made possible the formation of an awareness of the symbolic unity of humanity as political reference.

Keywords: Humanitas. Humanism. Scipionic Circle. Mos Maiorum. Stoicism.

\section{Introdução ${ }^{1}$}

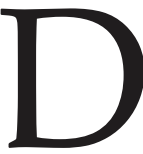

entre os estudos propedêuticos acerca do tema do «humanismo», diversos costumam defini-lo e interpretá-lo como sinônimo de «antropologia filosófica». Os estudiosos, em geral, definem-no como o fundamento antropológico sobre o qual se edificou a filosofia de autores canônicos como Platão, Aristóteles, S. Agostinho, Hobbes, Rousseau e Marx. Desejam, assim, reinterpretar a história da filosofia ocidental a partir de uma hermenêutica antropológica do cânone, sobretudo ao referirem-se à onipresença de questões metafísicas clássicas como os temas da «natureza humana», da «condição humana», do «homem natural» ou da «existência». Há uma vasta bibliografia que reitera a mixórdia entre os termos - humanismo e antropologia filosófica - sobretudo quando propõe categorias taxonômicas como humanismo cristão (Gabriel Marcel, 1947), humanismo renascentista, humanismo antigo, humanismo científico, humanismo secular, humanismo integral católico (Maritain, 1945) humanismo hebraico ou hassídico (Buber, 1923), humanismo latino (Paviani, Bombassaro e Dal Ri Jr, 2004), humanismo teocêntrico, humanismo existencialista cristão, humanismo existencialista ateu (Sartre, 1945), humanismo marxista (Garaudy, 1957; Fromm, 1970), humanismo socialista, humanismo heideggeriano e anti-humanismo (Foucault, 1966).

Tais proposições taxonômicas podem ser atestadas em vários manuais de antropologia filosófica (ou humanismo), como é o caso do conhecido livro de Pedro Dalle Nogare, Humanismo e Anti-Humanismos. Introdução à Antropologia Filosófica, o qual, somadas suas quatorze edições, é, provavel-

\footnotetext{
${ }^{1}$ Dedico este artigo ao Bispo Dom João Evangelista Martins Terra, a quem jamais conheci pessoalmente, mas cuja obra magnífica me inspirou a redigir este breve estudo.
} 
mente, o maior difusor deste imbróglio no Brasil, ao lado de outra dezena de obras². Em sua maioria, estes manuais de apresentação do tema não distinguem entre humanismo, antropologia filosófica e analítica existencial do ser. Por outro lado, a taxonomia proposta por eles desconsidera os estudos científico-naturalistas do homem tais como a etologia humana (Eibl-Eibesfeldt, 2017), a paleoantropologia (Tatersall; Schwartz, 2005) e a biossemiótica (Favareau, 2010). Consideram como relevantes tão somente as «poéticas do homem», como as definira Arnold Gehlen (1993), isto é, as interpretações metafísicas, deístas, essencialistas, ideológicas ou existencialistas do humano ${ }^{3}$.

A mixórdia entre estes dois termos, tratados como unívocos e cambiáveis por vasta bibliografia, torna-se ainda mais confusa quando verificamos a acepção admitida pelo étimo «humanismo» na área dos estudos literários. Da perspectiva de autores como Ernst Curtius, Erich Auerbach, Erwin Panofsky, Leo Spitzer e Werner Jaeger - para exemplificarmos com autores que não compõem o escopo problemático deste breve estudo - o humanismo diz respeito à formação (Bildung) do homem segundo certo cânone de leitura e certo método no tratamento de fontes histórico-filológicas. Trata-se, neste caso, de uma tradição filo-helenística a qual resgata a studia humanitatis romana tal como fora proposta pelos humanistas do Renascimento nos séculos XIV e XV e, três séculos depois, pelo teólogo e pedagogo bávaro Friedrich Immanuel Niethammer (1808), criador do neologismo «humanismus» (vocábulo derivado da palavra ítalo-latina «umanista», muito usada durante o período do Renascimento italiano para designar tão somente o ofício do professor secundarista responsável pelo ensino de disciplinas clássicas como Gramática, Retórica, História, Filosofia Moral e Poesia). Uma vez que o termo «humanismo» proveio tardiamente da palavra «humanista» e esta, por sua vez, proveio de humanitas, constatamos que a reconstituição da origem do termo, bem como a reconstituição das variações de significado pelas quais passou, reivindica o mapeamento histórico-conceitual da volatilidade dos significados a ele atribuídos ao longo de dois milênios. Tarefa árdua, impossível ante a brevidade de um simples artigo, mas que não nos impede de examinar, ainda que brevemente, a origem experiencial e semântica do termo humantitas. Afinal, revolver à origem nos permitirá desfazer alguns dos inúmeros imbróglios provocados pelo emprego inadvertido do termo «humanismo». Neste estudo trataremos não apenas da origem da palavra humanitas desde o primeiro emprego escrito por Marco Túlio Cícero até sua aparição no Panegírico a Trajano (de Plínio, o jovem);

${ }^{2}$ Cf. Garaudy, 1965; Agosti, 1970; Etcheverry, 1975; Marías, 1975; Groethuysen, 1988; Puledda, 1996; Bombassaro, Paviani e Zugno, 2003; Stein, 2003; Mezzaroba, 2008; Oliveira, 2006. 3 Alhures discorremos acerca das diferenças inconciliáveis entre o «humanismo» e a Antropologia Filosófica (Almeida, 2019). Se o primeiro «conceito» se constituiu a partir de uma dada Filosofia da História, o segundo só pôde desenvolver-se como expressão de uma dada Filosofia da Natureza. 
nosso propósito é, sobretudo, investigar como se tornou possível, na história das civilizações antigas, a percepção simbólica da unidade do humano a despeito do estranhamento provocado pelas diferenças entre os povos.

O propósito, portanto, não se resume em reconstituir a trajetória etimológica, filológica e conceitual do termo humanitas desde sua origem estoica, mas em compreender porque o conceito, desde sempre, apresenta um núcleo semântico inconstante, volátil e aberto. Mais do que examinar os materiais bibliográficos em busca de evidências filológicas, tentaremos apreender como se deu o surgimento das estruturas de consciência que possibilitaram a percepção da humanidade como símbolo universal de todos os habitantes da terra habitada, a oikouménē. Esta percepção tornou-se possível em razão da passagem das representações mitopoéticas compactas do homem para uma compreensão noética e conceitual; tal noética se desdobrou, no período estoico posterior, numa allegoresis representativa, conforme a definiu Eric Voegelin. Estas transitividades no que diz respeito às formas de autocompreensão do humano implicaram na ruptura com a mitopoética pátria (fundada no sentido simbólico da representação homem-terra) e engendraram uma representação desterrada, cosmopolita, abstrata e receptiva a qualquer conteúdo politicamente atribuível. Esta metamorfose noético-alegórica antecedeu e determinou o surgimento do tardio conceito romano da humanitas. Se nos ativermos tão somente às evidências filológicas, como o fazem a maioria dos estudiosos da questão, não poderemos compreender plenamente porque o sentido do termo passou a variar conforme as convicções - filosóficas, teológicas e políticas - dos agentes em diversos contextos históricos. É necessário compreender o conjunto das experiências simbólicas a fim de não julgarmos o conteúdo volátil do termo como algo natural, irrelevante ou espontâneo.

Mais do que uma palavra, humanitas definia-se, desde a origem, como um código de conduta criado durante o período da Baixa República Romana no contexto das Guerras Púnicas para fins diplomáticos e paidêuticos. Investigaremos o uso do conceito desde o primeiro registro escrito nas obras publicadas pelos membros do Círculo Cipiônico até o emprego da palavra pela tradição panegírica da era imperial augustana. Portanto, investigaremos os usos do termo no intervalo que se estende entre século II a.C. e o século III da era Cristã. Esta demarcação cronológica não é arbitrária tendo em vista que a palavra passou a ter, desde o contexto da Roma Imperial e da hegemonia estoica, uma denotação distinta, assim como, posteriormente, após o século III d.C (a partir da era constantiniana) passou admitir em seu núcleo semântico um sentido cristológico determinado pelas controvérsias acerca da humanidade e/ou deidade de Cristo (Navarro Girón, 1990).

O estudo que ora propomos está subdividido em quatro partes, a saber: 1) uma breve investigação etimológica acerca das origens mitopoéticas 
dos termos homólogos à palavra homō, quais sejam, anér, dhghom, gumōm, manu e Ad'Ham; 2) um exame acerca da passagem da simbólica mitopoética para a representação noética do homem; a degeneração desta compreensão noética após o declínio da Hélade clássica abriu caminho para a assunção de uma representação alegórica do humano no período estoico, época na qual foi cunhado o termo humanitas; 3) uma exposição acerca da origem do conceito de humanitas nos círculos cipiônicos enquanto expressão da luta hermenêutica pelo monopólio do conceito de romanidade (romanitas), luta esta travada entre os tradicionalistas defensores do mos maiorum e os helenistas da grei cipiônica; 4) um brevíssimo exame acerca dos primeiros registros escritos do termo humanitas por Cornificius, Cícero e pelos panegíricos imperiais da era augustana, entre outras fontes.

\section{Breve etimologia de homo e seus homólogos}

A palavra latina homō deriva do substantivo humus, que significa chão, solo, terra, húmus. A etimologia tardo antiga de Santo Isidoro de Sevilha (560-636 d.C.) atentava para esta associação entre homo e humus na célebre passagem: Homo dictus, quia ex humo est factus (XI, i, 4$)^{4}$. Antes do tratado de etimologia do sábio de Sevilha, Quintiliano (35 d.C. a 95 d.C.) já enfatizava na Institutio a associação entre terra e homem: «etiamne hominem appellari quia sit humo natus» $(1,6,34)^{5}$. Os étimos latinos que deram origem ao termo homem - hümānus e homō - provêm de humus, que por sua vez tem a mesma origem que as palavras gregas chóma $(\chi \omega \mu \alpha)^{6}$ e chamaí $(\chi \alpha \mu \alpha i)$, as quais também designam os substantivos solo, terra e húmus (Valpy, 1860; Buck, 1984). Daí advém, por exemplo, a justaposição dos termos $\alpha u ̉ \tau o ́ s$ (autos) e $\chi \Theta \omega ́ v$ (khthon), isto é, autóctone, homens que surgem da terra, que, por sua vez, filia-os a um destino, a patris ( $\pi \alpha \tau$ Qís), terra dos ancestrais e dos que hão-de vir.

Os dicionários etimológicos de Ernout \& Meillet (2001) e Buck (1984) enfatizam que homo era redigido também hemo, ambos derivados de duas palavras matriciais indo-europeias cujo significado é terra (no sentido físico de «solo» e no sentido político-territorial de «pátria»), quais sejam, dhghem e dhghom (Buck, 1984, p.16; Ernout \& Meillet, 2001, p. 297-298; Pokorny, 1959 , p. 412), como podemos deduzir, ambas muito próximas do grego

\footnotetext{
${ }^{4}$ «Chamamos assim ao homem (homo), porque é feito do humus (barro)». p. 845, 2009.

5 «E ainda se denominar homo por ter nascido do humus [...]» p. 141, 2015.

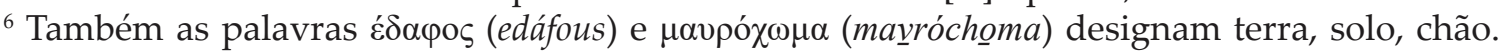

7 Segundo Ernout \& Meillet: «Humus se encontra em todas as épocas. O céltico tem em irlandês: uim, humol; em britânico ufyll, ufylldod; em grego chton e chamai; em védico Ksah, locativo ksah, locativo ksami, genitivo gmáh; antigo irlandês $d u$, genitivo don, em avéstico $z a$, genitivo zemo, locativo Zemi; em hitita tegam». (p. 298)
} 
khthon. É este radical indo-europeu que dará origem ao gótico-germânico gumōm e o latim homō. O homem é, desde esta genealogia filológica, humus, isto é, nascido da terra, terrestre, por oposição às divindades celestes (Terra, 1999, p. 282). E esta terra que o gera, filia-o a uma pátria. O sentido terrestre e terroso, como é sabido pela Teologia cristã, dá origem a termos como humildade e exumar, por exemplo.

Nesta lógica, a origem de homo difere da origem grega de $\ddot{\alpha} v \theta \varrho \omega \pi 0 \varsigma$ (anthropos), palavra que, segundo Isidoro, provém do fato de o homem erguer-se «desde o solo (sublevatus ab humo)» e olhar por cima (sursum spectet) «em contemplação ao seu Criador» (XI, i, 5). Alguns dicionários de etimologia latina (A. Ernout \& A. Meillet, 2001, p. 464; Valpy, 1860, p. 12-13) remetem o significado de anthropos à justaposição dos radicais anér (ảvío) e opos (ỏ $\varphi \theta)$. O radical ner designa não apenas o substantivo «homem» (no sentido de «macho», «adulto»), mas também os adjetivos «vital», «forte» e «vigoroso». Este sentido é o que opõe «homem» aos substantivos «Deus», «mulher» e «criança». Porém, anér pode designar também ambos os sexos, quer dizer, pode ser empregado com denotação universal ao gênero humano, macho e fêmea. Já opos é o genitivo de óps $(o ̉ \varphi \theta)$, isto é, face, semblante, olho. Logo, anthropos literalmente significa «aquele-que-tem-face-de-homem» ou «aquele-que-tem-olhar-de-homem» (Buck, 1984, p.80). Por outro lado, a principal fonte de palavras para «homem» não está restrita à noção de «terrestre», mas também de «mortal», caracteres que distinguem os homens dos deuses (imortais e celestes).

Há também especulações acerca a raiz hitita de anthropos. Robert Steve Paul Beekes assinala que, embora haja semelhança entre os termos hititas que designam «homem», quais sejam, anteuuahhas e antuhs em relação ao grego anthropos, não podemos assegurar o substrato semântico originário comum a ambas as fontes porque o termo hitita deriva dos radicais hen e dhuehs, que significam, justapostos, «ter-ânimo» ou «espírito-interior». Em grego, equivaleriam a $\theta u \mu o \varsigma$ (thymós), ira, cólera (2010, p. 106), o que nos dá evidências da improcedência da associação. Para Beeks não há provas etimológicas suficientes que assegurem a origem de anthropos, certamente por ser, a palavra em si, um substrato simbólico originário e primordial.

Se rastrearmos a origem do grego anér e do latim homō no vocabulário protoindo-europeu veremos que os termos correspondentes são os étimos manu(-s) ou топи(-s). Esta origem pode ser averiguada nos dicionários indo-europeus de Carl Darling Buck (1984), Julius Pokorny (1959), bem como no clássico Grundriss de Karl Brugmann e Berthold Delbrück (1892). Se revolvermos mais no tempo, podemos encontrar as raízes semânticas de manu e monu no sânscrito, língua cuja grafia da palavra «homem» redige-se igualmente manu (मनुस), manus e manusa. Teríamos aí um indício da origem mais remota da palavra, porém, como afirma Buck, as conexões entre tais fontes semânticas - protoindo-europeia e sânscrita - são totalmente 
incertas. De todo modo, a palavra sânscrita «manu» nomeia o ancestral arquetípico da humanidade, o décimo quarto progenitor dos homens e legislador da terra, também chamado Svayambhuva. As fontes sânscritas indicam que manu está relacionado a atributos como "pensamento", «inteligência»e «sabedoria». Esta origem, portanto, acentua a faculdade intelectiva que difere o homem dos animais (Buck, 1984).

A mesma origem térrea e chã do homem pode ser constatada na etimologia

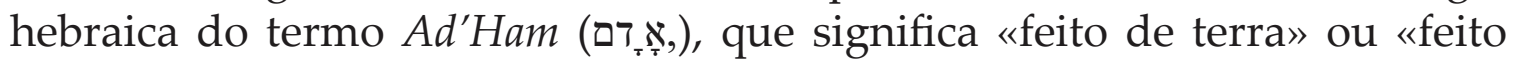
de barro» (Gen. 2,7; 3,19). Trata-se, neste caso de um anagrama de Adamah, isto é, «solo» ou «terra». O nome «Adão», conforme aparece no livro de Gênesis (Beresheit), é redigido com o artigo $A d$ («O Homem»), de forma que pode ser interpretado como o arquétipo progenitor da humanidade em sua origem, e não simplesmente como um nome próprio, pessoal. Se assim o for, estaria subentendido que tal arquétipo representa a unidade da espécie humana, sobretudo por seu caráter seminal e originário ${ }^{8}$. Esta é a tese esposada, por exemplo, no Apócrifo II, de Enoch (ou Enoch Eslavo). Neste sentido, os relatos da literatura rabínica e apócrifa referem-se à criação de $A d^{\prime} H a m$ a partir da recolha de terra das quatro partes do mundo. Deus teria recolhido porções de terra de um lugar sagrado, misturando-a com outras porções oriundas do norte, sul, leste e oeste; a tais porções foi acrescida água dos quatro mares, o que a tornou uma terra vermelha (compósita do sangue e da pele de $A d^{\prime} H a m$ ), negra (o intestino), branca (os ossos e nervos) e verde (o fígado). Adão fora feito do húmus das quatro regiões da terra expressas nas quatro letras de seu nome: Anatole (leste), Dysis (Oeste), Arktos (Norte) e Mesembria (Sul). Esta narrativa ${ }^{9}$ da natureza «cosmopolita» do primeiro homem é ratificada, mutatis mutandis, pela Etimologiae de Santo Isidoro de Sevilha, especificamente na obra De Natura Rerum. O bispo declara que Adão fora feito de sangue (sanguis), bílis (chole), bílis negra (atrabilis) e fleugma, não por acaso, os quatro temperamentos constitutivos da doutrina dos humores legada de Hipócrates e Galeno (Panofsky, Klibansky e Saxl, 2019). Estes humores corresponderiam às quatro estações do ano e aos quatro elementos da natureza (terra, água, fogo e ar). Portanto, o nome «Adão», uma vez que designa «homem» (no sentido de «macho» e de «o primeiro homem da humanidade»), tem sua tríplice raiz semítica nas palavras אדום, isto é, adom (vermelho), admoni (corado) e dam (sangue). O tom vermelho da pele humana é o mesmo da cor vermelha do solo arável, isto é, o אדמה (adamah). Estas seriam as bases semânticas relativamente consensuais acerca da origem do nome

\footnotetext{
${ }^{8}$ A interpretação Católica costuma enfatizar o caráter coletivo de Ad'Ham (no sentido de «humanidade»), mais do que o caráter singular, designativo de um único homem. A interpretação exaustiva de F. Stier (1983, p. 21-36) afirma que, caso designasse um único homem, redigir-se-ia ben-âdâm, isto é, «o filho do homem pertencente à estirpe humana».

${ }^{9}$ Cf. J. Frederic McCurdy, Kaufmann Kohler, Richard Gottheil, Jewish Encyclopedia. "Adam" (verbete), Vol.1, p. 173-179, 1906.
} 
«Adão». Porém, por outro lado, há divergências, como seria o caso dos filólogos cuja tese é de que Adamah deriva do sânscrito Adima, que significa «o progenitor», «o primeiro» (Gesenius \& Tregellis) ${ }^{10}$. Importa-nos por ora que o simbolismo mitopoético da origem do homem esteve quase invariavelmente relacionada à terra e à pátria como lugar irrevogável de pertença e geração. Cabe-nos agora saber como tal simbolismo fora violado pelo espírito noético da civilização helena e pela artificialidade literária da filosofia estoica.

\section{Da simbólica mitopoética à allegoresis da representação humana}

Portanto, interessa-nos que o sentido térreo convergente às raízes etimológicas dos termos homō, anér, dhghom, gumōm, manu e Ad'Ham reforça a tese segundo a qual a palavra homem está, quase invariavelmente, fundada numa simbologia política da pertença e da simbiose homem-terra. Trata-se de um símbolo político trino: homem-terra-pátria. Portanto, tal mitopoética antropogênica da simbiose homem-terra está marcada pela representação do fenômeno humano como coextensivo (ou consubstancial) à natureza, ao cosmos e ao divino.

Contudo, para além destas evidências etimológicas primordiais, precisamos investigar como o símbolo da humanidade - enquanto grandeza política e atributo qualitativo do humano - surgiu entre as civilizações da história. Não se trata agora de um exame dos materiais etimológicos, mas da apreensão das estruturas de consciência que permitiram perceber e nomear a humanidade como símbolo universal de todos os habitantes da oikouménē. Para tanto, nos deslocaremos da etimologia para a história da experiência dos modos de simbolização das civilizações da antiguidade. Qual foi a civilização cuja experiência simbólico-espiritual deu origem a percepção da humanidade como grandeza política e moral? Quem foi o sujeito oculto por trás dessa humanitas abscondita (Voegelin, 2010, p. 58)? Como esta estrutura de consciência tornou-se possível se a humanidade

\footnotetext{
${ }^{10}$ Outros afirmam que Adamu seria, também, o primeiro na lista dos reis assírios. Já Kenneth L. Barker (1985) afirma que Adamah, no sentido de «humanidade» provém da língua canaanita. Outros referem-se ao acádio Adamu que significa «para modelar» ou «para ser feito», assim como há aqueles que sustentam a origem cabalística de Adame, que significa «eu-devo-assemelhar-me», no sentido de assemelhar-se a Deus (Shelah HaKadosh). Para uma exposição sistemática acerca do termo «Adão» conferir, além da Enciclopédia Judaica, o verbete do Dicionário de Teologia organizado por Heinrich Fries (p. 21-36). O núcleo da divergência entre a interpretação Católica do símbolo adâmico e a teologia judaica do povo eleito está, como dissemos, no caráter coletivo de Adão como representante universal da humanidade em contraposição ao caráter singular esposado pelo judaísmo.
} 
não se constituía numa organização política concreta? Esta irrupção ocorreu de chofre ou se deu de forma progressiva?

Dentre as tentativas de responder a estas questões estão a tese da Era Axial, ou Achsenzeit de Karl Jasper (1968, p. 20) ${ }^{11}$ e a tese da Era Ecumênica de Eric Voegelin $(2010)^{12}$. Enquanto a primeira entende que a formação da autoconsciência do homem se deu «sem o apoio de uma determinada fé» (Jaspers, 1968, p. 19); a segunda julga, contrariamente, que tal autoconsciência adveio da tensão com a realidade divina, uma vez que «o ser humano se conscientiz[ou] de sua humanidade como existência» quando reconheceu em si a tensão com a realidade divina. Tal realidade, enquanto evento hierofântico-espiritual produtor de símbolos, engendrou «o conhecimento da existência do ser humano no intermédio divino-humano, na Metaxia de Platão» (2010, p. 58). Se levarmos a sério as evidências etimológicas anteriormente apresentadas, bem como a pletora de materiais históricos mobilizados por Voegelin para comprovar sua tese, não podemos deixar de rejeitar parcialmente a hipótese de Jaspers ${ }^{13}$. O gesto de prestidigitação dos elementos hierofânticos em favor dos elementos noéticos nascentes atribui aos agentes históricos da antiguidade um caráter proto-secular que não estava em seus respectivos horizontes, mesmo entre os Helenos, cuja relação com o divino era tão estreita quanto o era nas religiões de

\footnotetext{
${ }^{11}$ Jaspers demarca este tempo-eixo (ou Era axial) nos seguintes termos: «Este eixo da história universal parece estar situado cerca de 500 anos antes de Jesus Cristo, no processo espiritual ocorrido entre os anos 800-200. Ali está o corte mais profundo da história. Ali tem sua origem o homem com o qual vivemos até hoje. A esta época chamaremos abreviadamente de 'tempo-eixo' [...] Neste tempo concentram-se e coincidem multidões de fatos extraordinários. $\mathrm{Na}$ China vivem Confúcio e Lao-Tsé, Mo-Ti, Chuang-Tse, Lie-Tse e outros muitos. Na Índia surgem os Upanixades, vive Buda; desenvolvem-se, como na China, todas as possíveis tendências filosóficas, desde o ceticismo ao materialismo, a sofística e o niilismo. No Irã ensina Zaratustra a excitante doutrina que apresenta o mundo como o combate entre o bem e o mal. Na Palestina aparecem os profetas, desde Elias, seguido por Isaías e Jeremias, até o Dêutoro-Isaías. Na Grécia encontramos Homero, os filósofos - Parmênides, Heráclito, Platão -, os trágicos, Tucídides, Arquímedes. [...] A novidade desta época é que nos três mundos [China, Índia e Ocidente] o homem eleva-se a consciência da totalidade do Ser, de si mesmo e de seus limites.» (1968, p.20). Desde Toynbee, pelo menos, sabemos que a tese jasperiana da Era Axial não tem sustentação empírica. Zaratustra, Moisés, Jesus e Maomé situam-se, cada qual, antes ou depois do intervalo axial. De todo modo, para Jaspers o tempo-axial legou-nos, até hoje, o caráter universal da história e uma «profunda compreensão recíproca» (idem, p.27) que não poderíamos encontrar nas civilizações mais antigas (sumérios, assírios, egípcios, hititas, babilônios, etc.).

${ }_{12}$ Por motivos de economia textual não abordaremos aqui às diversas teses acerca desta questão, dentre as quais destacam-se as investigações de Edward Meyer (Geschichte des Altertums), Max Weber (Ensaios de Sociologia da Religião), Oswald Spengler (O Declínio do Ocidente), Arnold Toynbee (Um Estudo de História) e Shmuel N. Eisenstadt (Axial Civilizations and World History).

${ }^{13}$ Não somente Voegelin esposa esta tese da origem da autoconsciência do homem como resultado da tensão com a realidade divinamente revelada, mas também Hannah Arendt ao assinalar que «a questão da natureza do homem é uma questão teológica tanto quanto a questão da natureza de Deus; ambas só podem ser resolvidas dentro da estrutura de uma resposta divinamente revelada» (Arendt, 2011, p. 12).
} 
revelação (Burkert, 1993). Daí se depreende que o tempo axial nada mais fora que um tipo de «simbolismo pelo qual um pensador moderno tent[ou] enfrentar (sendo páreo para isso) o perturbador problema de estruturas significativas na história» (idem, p. 58). As irrupções simbólico-espirituais que deram origem às civilizações - dos sumérios aos muçulmanos - foram, em verdade, irrupções nas formas de autocompreensão do homem em sua relação com o cosmos e o divino.

Como afirma Voegelin, para compreendermos a contento os modos da relação humana com o divino (e a consequente formação da autoconsciência) devemos aceitar que a história define-se, a rigor, como «[...] o processo de participação humana num fluxo da presença divina» a qual «possui uma direção escatológica». É da experiência com o divino que surgem as noções de tempo e humanidade. O tempo - passado, presente e futuro - materializa-se nas formas de simbolização do Escathon e suas instituições derivadas, quais sejam, os mitos de origem, os rituais fúnebres, o julgamento post mortem e a ressurreição ${ }^{14}$. Já o símbolo da humanidade, segundo Voegelin, tornou-se possível a partir da tensão existencial que se estabeleceu - nas religiões de revelação (Israel) e na consciência diferenciadora da Hélade - entre o homem e sua participação na realidade divina supracósmica. A presença de um deus oculto (Hester Panim) ou demiurgo incognoscível (ainda que experienciado sensorialmente através da meditação, das visões, divinações e audições) engendrou a consciência diferenciadora da humanidade como contraparte da presença divina. Tal experiência exigiu sua própria nomeação, e desta exigência surgiram conceitos como pneuma, nous, psique, theotes, epekeina e aner. Como assinala Voegelin, o homem, após participar de um «evento teofânico», tornou sua consciência "cognitivamente lúcida por sua própria humanidade enquanto constituída por sua relação com o deus desconhecido cuja presença movente em sua alma evoc[ou] o movimento de resposta» (idem, p. 61).

Voegelin parte do pressuposto segundo o qual as experiências epifânicas e teofânicas dos profetas não são alucinações, como poderia julgar a filosofia iluminista moderna. Contrariamente, são modos de irrupção espiritual que devem ser tomados como experiência concreta uma vez que foram assim descritas pelos narradores. Não podemos tomar por falsa ou ilusória uma experiência sensória descrita como verdadeira por quem a vivenciou. Devemos partir de uma hermenêutica da confiança quanto à potência representativa dos símbolos (Ricoeur, 1978), não de uma hermenêutica da

\footnotetext{
${ }^{14} \mathrm{O}$ Livro dos Mortos, uma preciosidade egípcia milenar encontrada, traduzida e publicada por Wallis Budge (1985) é, certamente, o documento histórico par excellence da temporalidade apeirôntica - o ser e vir a perecer - e sua relação com o divino. A partir destes rituais fúnebres tornou-se possível conceber a noção de futuro. E a noção de futuro e de julgamento post mortem fora assimilada pelos judeus em razão das estreitas relações com a religião egípcia antiga (Sousa in Luís Manuel de Araújo, 2001, p. 234-236).
} 
suspeita. Por outro lado, quando aproxima a verdade da autoconsciência do ser humano e a hierofania da presença participativa no divino Voegelin reafirma a tese primordial da filosofia da religião de Max Scheler, para quem a autocompreensão do homem surge quando ele é capaz conceber a unidade maximamente formal do transcendente (Scheler, 2015). É a realidade da presença divina que - ao prover o significado da origem e do além, da criação e do Escathon - torna lúcida a consciência mediante a simbolização do intermediário, isto é, torna lúcida a posição do homem no cosmos e a própria condição finita.

Na medida em que surgiram os símbolos da revelação e da sabedoria, os mitos cosmogônicos e seus deuses intracósmicos passaram a ser explicados noeticamente, o que resultou numa desdivinização do cosmos. $\mathrm{O}$ esvaziamento do caráter sagrado do mito e a desdivinização da natureza abriram vácuos de significado simbólico que demandaram seus respectivos significantes. Assim surgiu o estoicismo, quando o discernimento noético converteu-se em doutrinação religiosa, isto é, quando a verdade dos símbolos da experiência desprendeu-se de sua raiz existencial e passou a flutuar arbitrariamente como mero silogismo lógico-linguístico de hipóstases conceituais autorreferentes. Foi a partir dessa flutuação que a verdade noética da filosofia platônico-aristotélica converteu-se em doutrina religiosa. Como assinala Voegelin:

[...] quanto mais abstrata se torn[ou] a linguagem da tensão [da matéria em relação à sua forma e da realidade cósmico-divina em relação à alma humana], mais suscetível esta[va] seu usuário de esquecer que a linguagem é parte do encontro divino-humano no qual a tensão do ser humano na direção do fundamento torna-se lúcida a si mesma (Voegelin, 2010, p. 93).

Este processo de olvido do lugar terreno e concreto dos símbolos ocorreu porque o movimento estoico preocupou-se sobremaneira em nomear a tensão (tasis) mais do que compreender o caráter autóctone da narrativa mítica no intermediário. Daí que autores como Panécio considerassem a fé em adivinhações ou os discursos deístas uma «autêntica estupidez» (Panécio in Radice, 2010, p. 198). Substituiu-se a cosmogonia pela cosmologia. Numa palavra, o estoicismo pôs em curso um processo de mitificação da compreensão noética (e do próprio logos que a viabiliza) em conjunção com o desprezo radical pela simbolização mitopoética. O gesto de nomear fora, em si mesmo, um movimento de abstração da inteligência na tentativa de apreender a estrutura da realidade remetendo-se digressivamente a sinônimos. Os símbolos da experiência reduziram-se a meros jogos de linguagem.

A razão que outrora fora definida como uma operação do espírito cujo fim era aceder à estrutura da realidade tornara-se autônoma; converteu-se no próprio espírito hipostasiado, encarnado e onipresente. A palavra, portanto, desligou-se da experiência engendradora originária que a cunhou a tal 
ponto que se tornou autorreferente e autoevidente. Passou a designar a si mesma, isto é, passou a referir «um novo jogo intelectual com realidades imaginárias num domínio imaginário do pensamento». Daí que tenha se aberto «o jogo da metafísica proposicional» (Voegelin, 2010, p. 98).

Como sabemos, a palavra nous fora cunhada pelos helenos da época clássica para nomear uma experiência do espírito (Snell, 2003). A partir de um evento hierofântico, a alma movera-se em direção à compreensão da estrutura da realidade. Tal palavra não poderia surgir autopoieticamente de um jogo sinonímico ou de um dicionário matriz redigido por um demiurgo, mas tão-somente da tentativa humana de nomear uma experiência espiritual concreta. Contudo, o evento epifânico que deu origem a este vocábulo morreu «com o ser humano que foi por ele agraciado, ao passo que a linguagem permanec[eu] no mundo». Como assinalou Voegelin:

Quando entra na história, a verdade tem que carregar o fardo da morte e do tempo; e nas mãos de pensadores menores, que em certa medida são sensíveis à verdade, mas incapazes de reativar completamente a experiência engendradora, a verdade sobrevivente da linguagem pode adquirir um status independente da realidade originadora. A verdade da realidade que vive nos símbolos pode ser deformada numa verdade doutrinária acerca da realidade; e, como o objeto ao qual a verdade doutrinária refere-se proposicionalmente não existe, tem que ser inventado (Voegelin, 2010, p. 94).

Daí a movimento de materialização dos símbolos imateriais, tais como o Nous, o Logos, a Phýsis, o Éter, o destino, a necessidade, o Cosmos, os anos, os meses e as estações. Contrariamente, passou a haver, também, um movimento de desmaterialização de símbolos materiais, como aner, homo, pátria e oukoumene, os quais se tornaram abstrações reais cuja realização dependia da ideia estoica de kosmópolis, o não-lugar ou o lugar-ideia de uma pólis sem território. Este estado de perturbação e insegurança espiritual fora descrito por Cícero no Sonho de Cipião, sobretudo quando o orador romano decidiu despertar o personagem do sonho para que as interpelações dos interlocutores não ocorressem. Para Voegelin, a narrativa ciceroniana dos «sonhos estoicos» representou a fuga do mundo pós-alexandrino rumo ao mundo das doutrinas alegóricas da realidade (2010, p.95). Findara a época do apogeu da pólis helênica e tivera início a expansão do Império Macedônico. Uma nova linguagem deveria ser inventada para preencher o vácuo espiritual de um império sem caráter, e, para tanto, seria a linguagem alegórica a matriz sintática daquela novilíngua imperial. Os artifícios alegóricos deformadores da experiência da realidade transformada em mero jogo linguístico de «ideias» teriam por objetivo:

[...] minimizar a magnitude da ruptura epocal na história, simulando que, afinal, não foi muito que aconteceu e encobrindo, mediante essa simulação, a falta de vontade ou incapacidade de enfrentar os problemas espirituais de humanidade universal que haviam sido criados pela ruptura (Voegelin, 2010, p. 95). 
A exposição das novas gerações à pluralidade de símbolos de caráter noético e mitopoético de várias regiões do ecúmeno engendrou um pluralismo cético, descrente. $\mathrm{O}$ estreitamento do contato multiétnico com persas, egípcios, macedônios, romanos e cartagineses, entre outros, passou a plasmar a consciência experiencial do símbolo da humanidade como grandeza política conforme se ampliavam os limites do mundo habitado. A perda da unidade espiritual e política era irreversível e, a despeito desta irreversibilidade, ainda não havia um deus universal disponível para equacionar a algaravia babélica do ecúmeno. $\mathrm{O}$ estoicismo preferiu, assim, «a literalização do simbolismo intermediário de Platão» (Idem, p.96), isto é, a derrisão, o escárnio e a cavilação (Macróbio, Comentário ao Sonho de Cipião, 1, 1, 8; 2, 5). A solução estoica oferecida para resolver a necessidade de uma filosofia política apropriada à sociedade ecumênica se dera com a proposição das ideias de kosmópolis e megalópolis (de Fílon de Alexandria). Tal solução fora espiritualmente expressa no Hino a Zeus, de Cleanto (in Dumont, 2004), bem como na eleição da apatia e da ataraxia como virtudes pessoais máximas, a despeito do caráter despolitizador que as define.

Contudo, a transformação da sabedoria filosófica em doutrina religiosa pelos estoicos não foi de todo maléfica. O Pórtico teve a virtude de salvaguardar a herança platônico-aristotélica em meio à sucessão de vicissitudes resultantes da dogmatomaquia imperial da era ecumênica. Os riscos de desintegração da consciência noética diferenciadora, herança do áureo período clássico, eram bastante claros, sobretudo para um grupo de romanos helenizados, responsáveis por fundar o Círculo Cipionnico. Mais do que orquestrar o nascente processo de helenização romana no século II a.C., estes homens se propunham preservar, mutatis mutandis, os principais tesouros legados pela filosofia clássica da Hélade. A palavra humanitas foi cunhada neste período, certamente, com o intuito de manter a observância cultual e doutrinária do legado grego, sobretudo no que diz respeito à Paidéia e ao significado diplomático da palavra, sinônimo de prudência (voũs) e

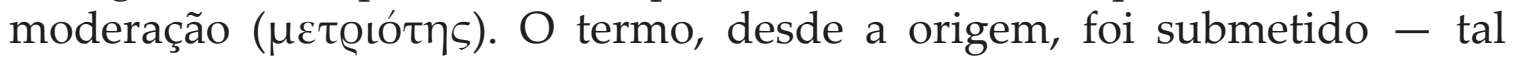
como ocorrera ao termo religio - à allegoresis que o tornaria ambíguo, estratificado em sinônimos superpostos, cada qual articulado à ética «em circunstância» do officiis ou kathēkon diplomático.

Por officiis (versão latina de kathēkon) Cícero designava a ética do dever de situação, que não se define por um dever absoluto ou sumo bem, tampouco por uma obrigação jurídica ou necessidade natural, mas tão somente pelo dever do decoro e da ação conveniente conforme a capacidade do agente, politicamente treinado, em ler as circunstâncias e resolvê-las (Agamben, 2013, p. 73-93). Humanitas não era, portanto, uma obrigação moral ou jurídica, mas um dever de circunstância cujo savoir-faire era adquirido mediante o treino político e paidêutico próprio aos membros do Círculo Cipiônico. Uma mesma ação diplomática pautada pela humanitas poderia ser considerada correta ou incorreta a depender das circunstâncias 
objetivas e subjetivas da ação. A diplomacia em si, enquanto atividade precípua do político, não seria um officium, mas uma ars, porque seus critérios de aproximação, conversação e decisão, eram (e ainda o são) variáveis conforme a particularidade do contexto e os atributos da pessoa que age em relação ao interlocutor que reage (Cícero, Fin., 4, 76). Como tal, a humanitas admitiria, simultaneamente, um caráter público e privado. A decisão em cada um destes âmbitos dependeria de uma avaliação acerca da ação cogente e suas consequências antevistas; as expectativas recairiam sobre cada um dos agentes conforme seus respectivos ofícios. A humanitas designava, portanto, a expectativa de comportamento de um dado homem público, cuja personalidade e perfil privado eram de antemão conhecidos pela comunidade, numa dada situação e no exercício de um ofício. Pressupunha um código de civilidade no trato para com os povos do ecúmeno sob domínio romano.

Por outro lado, humanitas designava também uma virtude situada no interstício entre o direito e a moral, entre a lei e o mos maiorum; como tal, ela definia a capacidade puramente humana de agir, expressa no autodomínio das paixões e no cuidado apropriativo próprio ao tratamento do outro. Numa palavra, enquanto virtude circunstancial, a humanitas designava o caráter eminentemente político da ação. Não obstante, o termo não definia o ser do agente, isto é, não o transformava num sacerdote secular da res publica, mas criava expectativas acerca do comportamento de uma dada pessoa pública; quer dizer, não se tratava de uma virtude tenaz ao agente, mas da predisposição consequente da ação que deveria visar o útil e não dar azo a ímpetos temerários ou iracundos. Embora fosse exercida pela pessoa em ofício e segundo a circunstância, a humanidade da ação seria avaliada pela comunidade segundo o critério da utilidade ao Império Romano. A ação diplomática humana não se definia como sumo bem cuja avaliação política e moral era considerada boa sem qualquer restrição; é a comunidade dos cidadãos da res publica quem avaliará e reconhecerá a humanitas da ação conforme a utilidade prática às coisas do povo. A palavra, portanto, preceituava a oportunidade do agir consequentemente segundo as circunstâncias e com vistas ao julgamento da comunidade. A humanidade do agir se realizaria no exercício de ser humano, isto é, no exercício que atualizaria ou tornaria efetual o munus da mansidão e da parcimônia, não por força de uma ordem externa, jurídica ou natural, mas pela utilidade consequente e pelo autocomando do homem que age e decide. A humanitas, neste aspecto, representava a faculdade humana de pensar, julgar, decidir e agir politicamente de modo que o conjunto destas faculdades transcendesse e concertasse num só gesto os limites impostos pelo direito e pela moral (mos maiorum). A ação de concertação entre o direito romano e o mos maiorum, o útil e o moral, é o que a definia. Não se trata aí do ser, reitero, mas do dever ser que se atualizaria na humanidade do agir como homem político. Este caráter político que define a humanitas 
é, portanto, de natureza republicana; em contrapartida, o personalismo do agente público define seu caráter imperial (Ahn, 2016).

Enquanto atributo optimates, próprio dos membros do Círculo Cipiônico, o conceito de humanitas já trazia em si os caracteres imperiais que o definiriam posteriormente no período do estoicismo augustano. Tais caracteres imperiais se desdobram do elemento «individual» que consubstancia a humanitas. Ela não pode ser uma «virtude» coletiva ou «social», mas tão somente um atributo do homem enquanto agente público. Em razão dessa característica «personalista», a virtude da humanidade da ação política seria, desde o Panegírico de Trajano, um símbolo da benevolência e da clemência do Imperador. Max Pohlenz já advertia, ao tratar do sentido último do livro De officiis, de Cícero, que o propósito do Arpinate era legitimar a liderança política (Führertum) da grei cipiônica. Podemos perceber como este mito salvífico do líder perpassa toda a história da península itálica, de Cícero a Dante (lembremo-nos da figura do veltro dantesco) ${ }^{15}$, de Dante ao Príncipe de Maquiavel. Pohlenz assim resume o afã pela assunção de um líder encarnado entre os membros do Círculo Cipiônico:

Cícero aderia ao ideal da época dos Cipiões, sonhava com um guia [Führer], com um novo Cipião, que, por intermédio da autoridade de sua pessoa, teria podido despertar à nova vida a antiga constituição romana e o bom tempo antigo [...] a época da libera res publica, na qual um homem político podia guiar o Estado apoiando-se somente no amor e na fidúcia do povo, havia desaparecido. Seria necessário um novo líder, que com um poder autoritário, mesmo que fosse ainda nas antigas formas, pusesse fim às lutas de partido. O próprio Cícero sentia que o ideal de liderança política [das Führerideal], que ele reconhecia, não era mais adequado ao presente. Daí o caráter trágico do De officiis (Pohlenz apud Agamben, 2013, p. 83).

O caráter imperial do conceito de humanitas, contudo, não se esgotava neste atributo da autoridade insubstituível da pessoa, posteriormente identificada como o Imperador ou o condutor $(d u x)$ augusto da grandeza romana. Tal caráter também se deixava ver perspicuamente no símbolo estoico do oikeiôsis, bem como na relação deste com os modos de espiritualização da oikoumenè estoica (a ideia de kosmópolis) ${ }^{16}$. Vejamos agora como se dava a relação antitética entre humanitas e mos maiorum. Tal contraponto

${ }^{15}$ Dante, Divina Comédia, Inferno, Canto I, 94-108, tradução de Cristiano Martins: «A fera hedionda, que te pôs clamando,/ não franqueia a ninguém a sua estrada,/ e a quem encontra nela vai matando//[...] Com bestas numerosas se acasala;/ e mais serão, até que por final/ o Veltro surja para aniquilá-la». Segundo Martins, o Veltro seria «um cão dotado de grande força; mas aqui designa alguém, possuidor de imensa virtude, cuja missão seria a de abater a loba (a avareza) e salvar a Itália». O Veltro seria, portanto, o vulto encarnado de um homem cuja virtude - imune à avareza e à usura - unificaria a Itália e combateria ferozmente as práticas corruptoras da república.

${ }^{16}$ Para uma sucinta investigação acerca da relação entre humanitas, oikeiôsis e kosmópolis ver o artigo: «Vicissitudes do Conceito de Humanitas: do Círculo Cipiônico à Tradição Panegírica Augustana». Disponível em: https:/jijiag2017.wordpress.com/programa/ 
nos permitirá compreender melhor o sentido romano da humanitas e sua permanente abertura semântica ao poder político.

\section{Humanitas versus mos maiorum}

O termo humanitas, fora, portanto, cunhado e difundido pelo Círculo Cipiônico, grupo composto por gregos e romanos grecizados responsáveis por promover o crescente processo de helenização da aristocracia romana. A grei fora fundada por Cipião Africano (236-183 a.C.), continuada por seu filho Cipião Africano (ca. 211/205-170 a.C) e, posteriormente, por seu sobrinho-neto e filho adotivo, Cipião Emeliano (185-129 a.C.) ${ }^{17}$. O Círculo Cipiônico perdurou por, pelo menos, três gerações. Sob o mecenato dos Cipiões reuniram-se poetas, filósofos, políticos, historiadores, edis curuis e cônsules; homens como Políbio (naquelas circunstâncias, um mero prisioneiro aqueu capturado na Batalha de Pidna, em 168 a.C., deportado e, posteriormente, recrutado como preceptor de Emeliano), Quinto Enio, Terêncio, Quinto Múcio, Panécio de Rodes, Caio Lucílio, Caio Lélio Sapiente, Fúrio Filo e Marco Túlio Cícero, entre outros. Era comum aos membros do Círculo receber a visita de filósofos, políticos e historiadores gregos, como foram os casos de Diógenes, Critolau da Babilônia e Carnéades, enviados ao Senado romano como representantes do Estado ateniense para tratar de questões diplomáticas. Os filósofos gregos recebiam prestativamente os membros da grei cipiônica, além de outros cidadãos romanos que desejassem tratar de assuntos acadêmicos como Retórica e Filosofia ${ }^{18}$. São diversos os relatos acerca das visitas de conferencistas gregos à Roma, como fora o caso também do estoico Crates de Malos, embaixador do rei de Pérgamo ${ }^{19}$, recebido em 159 a.C. Também as visitas de Possidônio, discípulo de Panécio e amigo de Pompeu, foram relatadas (78 a.C.). Mais do que diplomacia, tais encontros consolidaram os canais de intercâmbio entre as culturas grega e romana. Na obra de Cícero há diversas alusões aos diálogos (históricos ou fictícios, não se pode precisar $^{20}$ ) travados entre estes homens públicos.

\footnotetext{
${ }^{17}$ Rocha Pereira cita uma inscrição tumular de Lúcio Cornélio Cipião Barbado, Cônsul na Terceira Guerra Samnita, em 298 a.C. Nesta epígrafe, leem-se loas à sabedoria e à beleza de Barbado, numa clara alusão ao ideal da kalokagathia helênica. Quer dizer, o processo de helenização já estava em curso meio século antes do início da Primeira Guerra Púnica. A epigrama versa o seguinte: «Lúcio Cornélio Cipião Barbado,/Filho do Pai Gneu, varão forte e sábio,/cuja beleza igualou o valor;/Cônsul, censor, edil, ele foi entre nós;/tomou Taurásia e Cisauma no Sâmio,/submeteu toda a Lucânia, de lá trouxe reféns».

${ }_{18}$ Cicero, De Oratore, xxxvii.155-xxxviii.158, p. 311, 1967.

${ }^{19}$ Suetônio, De grammaticis et rhetoribus, 1979. 2,1.

${ }^{20} \mathrm{O}$ status quaestionis acerca da verossimilhança histórica do Círculo Cipiônico pode ser dividido entre aqueles que descreditam a existência do grupo (Austin, 1967; Strasburger, 1966) e aqueles que, a despeito de reconhecerem o caráter literário e artificial dos diálogos travados
} 
O mos maiorum pode ser definido como o código moral da vida comum dos cidadãos romanos conforme fora legado pelos ancestres e repassado de geração a geração desde a expulsão dos reis e a posterior fundação da República de Roma (ca.509-508 ou 503). Fundava-se, portanto, na observância pessoal e coletiva dos imperativos da fides, da pietas e da virtus. Por Fides os romanos designavam a garantia da boa-fé e da benevolência recíproca nas relações que se estabeleciam entre os cidadãos da República, fossem tais relações firmadas entre familiares ou sócios não familiares (socii). Tal garantia de boa-fé do povo romano (Fides Populi Romani) estendia-se aos vínculos ritualísticos e religiosos, isto é, às relações com os deuses, nas formas de juramento e pactos (foedus) firmados. Desde Numa Pompílio (753-673 a.C), a mantença da palavra dada se tornara mais imperativa que a própria virtude militar. Assim, o caráter coletivo e interpessoal da fides fora complementado pelo imperativo da pietas (Rocha Pereira, 2002, p. 338), isto é, a «obrigação para com aqueles a quem o homem está ligado por natureza (pais, filhos, parentes)». É a pietas o imperativo moral «que liga entre si os membros da comunidade familiar, unidos sob a égide da patria potestas, e projectada no pretérito pelo culto dos antepassados» (idem, p. 339). Em busca de proteção para sua família, o homem romano, portador da guardiania tutelar, deveria praticar a veneração das divindades a fim garantir boa fortuna. Daí que a pietas excederia o vínculo familiar até torná-lo um vínculo com as divindades (pietas erga deos), seja por dádiva ou comiseração numinosa. Numa palavra, a pietas designaria aí a lealdade política (para com a pátria), familiar (para com os parentes) e religiosa (para com os deuses) do homem romano. Por outro lado, designaria também a fé na providência dos deuses, isto é, a «atenção aos sinais dos deuses, pela fé em sua providência» (Marrou, 1966, p. 369). Daí, que a mantença e observância da pietas adviria de uma ordem imposta pela natureza segundo a lei universal e divina. A inobservância deste imperativo só poderia ser punida com a vingança, por vezes, das mais cruentas. Já a virtus definia o estado de ser homem recto, isto é, dotado de fides, pietas $e$ valentia (termo cujos congêneres gregos seriam andros e areté). Rocha Pereira (2002, p. 407) cita o conhecido fragmento 1326 M. de Caio Lucílio (180-103/102 a.C.) no qual o poeta afirma que «virtus é saber o que para

entre os personagens do Círculo nos escritos de Cícero, ainda assim, identificam evidências históricas capazes de comprovar a verossimilhança do grupo (Zetzel, 1972). Segundo Zetzel, «Cícero acreditava de fato na existência política e cultural do círculo». Quer dizer, o caráter literário dos personagens não anularia a verossimilhança histórica deles. Ademais, como assinala o intérprete, as conversações dispostas no De amicitia e no De republica transcorrem em dois círculos distintos criados pelo Arpinate. O De republica (redigido entre 55 e 51 a.C.) tem diálogos mais eivados de filosofia e vocabulário helenista, ao passo em que o De amicitia (redigido na época do afastamento de Cícero, em meio aos acontecimentos dos Idos de Março e do assassinato de Júlio Cesar, em 44 a.C.), remeteria o leitor aos assuntos da conjuntura política de Roma à época (apesar de seus personagens serem homens do século anterior). Neste caso, Amicitia teria um caráter mais político e autenticamente romano, contraposto ao caráter filo-helenista e cultural de De republica. 
o homem é reto, o que é útil, honesto». A virtus, contudo, não era uma virtude de caráter porque seus imperativos privados se voltavam para a preeminência da vida pública. Como enfatiza o dístico final de Lucílio, a virtus deveria "pôr em primeiro lugar o bem da pátria,/ em segundo o dos pais, e, em terceiro e último, o nosso». O caráter heleno-estoico de termos como rectum, utile e honestum estaria, neste caso, subsumido ao imperativo de serviço para com a res publica. Nesta lógica, o cidadão romano não deveria exercer tais virtudes para sua própria autossatisfação, mas para o bem da Cidade. Por seu caráter político, direcionado ao intercâmbio citadino e à praça pública, virtus tornara-se um imperativo cuja assimilação e exercício só poderiam ser realizados na prática, como afirmação em ato, não como doutrinação programática apreendida nos bancos escolares da filosofia ${ }^{21}$. Vê-se, portanto, que os imperativos de postura tinham finalidade política, isto é, voltavam-se para a res publica ${ }^{22}$, e o fundamento da res publica era o mos maiorum ${ }^{23}$.

Uma vez que o mos maiorum fundava-se, desde o fim do século VI a.C., nos imperativos morais do quadrinômio fides, pietas, virtus e res publica, podemos resumidamente defini-lo como um símbolo da tradição campônio-republicana das origens de Roma. Como tal, adviria da educação camponesa promovida pelo patriciado de campesinos e proprietários rurais que viviam da agricultura (Marrou, 1966, p. 358). Como sabemos, a fundação da República de Roma ocorrera, em verdade, a partir da sublevação dos patrícios campônios contra a dominação urbano-comercial dos etruscos e a imposição tirânica dos tarquínios (Plutarco, 1941). A expulsão dos reis e dos etruscos, naquele contexto, representou o triunfo do patriciado rural. Marrou assinala que esta origem campesina difere radicalmente, por exemplo, das origens guerreiras da epopeia helênica. Daí que o latim seja, igualmente, uma «língua de campônios» cujas palavras teriam uma origem etimológica agrícola, térrea. Por sua natureza telúrica e agrícola, o gênio da língua latina era «raso, pobre, concreto» (Marrou, 1966, p. 359).

\footnotetext{
${ }^{21}$ Tal amálgama de elementos helênicos aos itálicos pode ser também detectado em conceitos como honor («reconhecimento público do mérito, que atua como estímulo, e tem, por conseguinte, uma função pedagógica na cidade») e Dignitas (que refere-se ao exercício de cargos importantes e ao prestígio político do cidadão que ascende progressivamente no cursus honorum até chegar ao cargo de Cônsul ou Senador). Cf. Rocha Pereira, 2002.

${ }^{22}$ Por res publica designar-se-ia o Estado em si, ou, ainda, a organização mínima do Estado. Cícero, num célebre excerto, a define como «coisas do povo» (De res publica, I.32.48), isto é, «assuntos do povo» (I.25.39), contrapostos a res privata. Embora tenha uma provável origem estoica, a res publica se definia por elementos típicos da tradição romana. Daí que sua existência estaria condicionada ao vínculo jurídico e consensual entre os associados perante a lei e a comunidade de interesses.

${ }^{23}$ Como assinala Ronald Syme (1939, p.153), a definição de mos maiorum adquiriu tal amplitude que a expressão passou a ter um caráter meramente conotativo, isto é, passou a ser «um conceito vago e emocional». Para Syme, o mos maiorum não representava um código de lei constitucional. Seria um slogan da propaganda política evocado como símbolo de pertença, mas sem qualquer transitividade com a experiência política da Roma Imperial.
} 
Assim, o sistema de tria nomina refletia «o espírito símplice do camponês: prenomes sem imaginação: Primus, Quintus, Decimus; Lucius, Manius, Marcus», isto é, nomes cuja tradução literal seria: «nascido na alvorada, de manhã, em março» ou nomes como Fabius e Cicerus, literalmente, «fava» e «grão-de-bico».

A educação das crianças romanas demandava, neste contexto, a progressiva assimilação do modo de vida tradicional agrário-republicano. A elas eram transmitidas técnicas de trabalho agrícola (referentes à lavoura, à colheita e ao semeio), técnicas de criação das reses, além do aprendizado dos ciclos da lua e da presciência dos tempos de chuva. Cria-se, desde a origem, que o trabalho campesino seria responsável por formar o caráter do cidadão. Uma vez adulto, o homem deveria laborar, esforçar-se penosamente para ganhar seu sustento e ter honra diante da comunidade como autêntico pater famílias, aquele que gerencia com eficiência o patrimônio familiar. Havia, portanto, «amor ao trabalho árduo» (Marrou, 1966, p. 369). Rocha Pereira enfatiza que, para o homem romano, somente o fruto deste trabalho (fructus) seria «fructuosus, fecundus, fertilis, [...]». Neste aspecto, a formação dos romanos não poderia prescindir de uma ética do trabalho braçal, agrícola, baseado no esforço penoso e no manejo da terra, contraposto ao prazer (voluptas) da vida urbana e luxuosa então nascente à época de Catão-o-Velho. Daí que não houvesse na literatura latina da época republicana menções significativas acerca do labor litterarius, o qual, segundo Rocha Pereira (idem, p. 403), só viria a ser valorizado tardiamente no período augustano, quando a assimilação do gênio helênico pela romanidade já estava consolidada. Não obstante, autores de épocas distintas como Cícero, Varrão, Catão, Virgílio, Columela, Paládio e Gargílio são consoantes no que diz respeito a conceder ao labor campônio a primazia moral da vida republicana. Assim, a importância dada à arte agrícola pelos romanos difere qualitativamente da importância que vemos entre os gregos.

Tal privilégio da rusticidade agrorromana - baseada em elementos autóctones, tradicionais, pragmáticos, romanos, rudes, incultos e rurais - contrapunha-se radicalmente aos elementos adventícios, inovadores (res novae), teoréticos, heleno-cosmopolitas, polidos, literários e urbanos promovidos pelo Círculo Cipiônico ${ }^{24}$. Esta clara contraposição, contudo, não impedia a coexistência de elementos de consenso entre os tradicionalistas e helenistas. Os cipiônicos valorizavam, tanto quanto

\footnotetext{
${ }^{24}$ A correlação das forças políticas da Baixa República Romana era tal que, de um lado, havia um grupo composto pelos homo vetustus, isto é, o patriciado hereditário e proprietário de grandes extensões de terra; de outro, o grupo composto pelos homo novus, um segmento médio, sem poder político, cuja maioria era membro da ordem equestre. Cícero, por exemplo, era um homo novus. Daí Mommsen assinalar que os homo novus eram «Corifeus de um novo tipo de mentalidade que unia a tradição romana à paideia grega».
} 
os tradicionalistas, os fundamentos do mos maiorum e da República ${ }^{25}$. Não obstante, julgavam que a expansão imperial demandaria uma nova política diplomática tendo em vista que a língua grega representava, naquele contexto, o padrão universal de comunicação entre os povos do Mediterrâneo. Com o idioma helênico se redigiam os acordos diplomáticos e as tratativas internacionais.

Nesta lógica, o processo de helenização da cultura romana durante o século II a.C. resultou num conjunto de inovações políticas, filosóficas e culturais. Tais inovações deram-se pela transposição da linguagem política da experiência grega para a interpretação da experiência romana (Voegelin, 2010, p. 174). Como tal, esta transposição pressupunha uma analogia entre duas experiências civilizacionais. O processo de helenização, portanto, implicou na universalização artificial da cultura romana. A tradução latina do universo vocabular grego implicou numa recodificação etimológica dos conteúdos conceituais de origem helênica. O centro gravitacional de definição dos conceitos fora reformulado segundo os propósitos políticos e culturais da República romana. Fora

\footnotetext{
${ }^{25}$ Uma das mais célebres frases já escritas pela dramaturgia romana é de autoria de Publius Terentius Afer (ca. 184-185 - 159 a.C), ou simplesmente, Terêncio Africano, membro do Círculo Cipiônico. O personagem, Cremes, declama o seguinte senário iâmbico: «Homo sum: humani nihil a me alienum puto» (Heautontimorumenos, 77, 163 a.C.). Embora não haja neste excerto o emprego do termo humanitas propriamente, há o emprego de homo e humani. O ato I da peça de Terêncio desdobra-se a partir do diálogo entre dois velhos campônios (senex) que são vizinhos: um conselheiro e admoestador irônico chamado Cremes, e seu interlocutor, Menedemo, cuja relação conflituosa com o filho é narrada por ele próprio. Menedemo arrependera-se do tratamento austero dado ao filho, Clínio, no passado. Clínio preferira alistar-se no exército estrangeiro e partir para a guerra na Ásia a permanecer convivendo com a austeridade rústica do pai (pater durus). Sentindo-se culpado, Menedemo decidira vingar-se de si próprio, autoflagelar-se nos trabalhos diários em sua propriedade (daí o título da peça, Heautontimorumenos, isto é, aquele que se puniu a si próprio). Ao perceber tal comportamento de auto-mortificação e ouvir do próprio Menedemo a confissão dos motivos desta auto-punição Cremes sentencia: «Não dedicas tempo algum a ti mesmo, tampouco te observas». Menedemo então responde seu interlocutor com uma pergunta em tom zombeteiro: «Cremes, tamanho é o ócio de vossos afazeres a ponto de te ocupares com os afazeres alheios os quais não te dizem respeito?» A resposta, também irônica, de Cremes, é: «sou homem: nada do que é humano julgo ser alheio a mim». Trata-se de uma frase irônica que justifica o hábito da bisbilhotice mediante o uso de um topoi típico da filosofia estoica, qual seja, o imperativo do alargamento apropriativo do outro (oikeiôsis) como igualmente humano. Por outro lado, vemos aí um conflito entre os valores urbanos e joviais do filho em contraposição ao tradicionalismo rural do pai. Ao justificar sua intromissão, o velho Cremes, radicado nos princípios do mos maiorum da tradição agrorromana republicana, está também, em tom de deboche, fingindo comungar do imperativo estoico da oikeiôsis. A zombaria mútua entre os velhos ocorre, em verdade, como uma ironia de ambos para com os princípios cosmopolitas da filosofia estoica na medida em que fingem aderir a tais princípios ridicularizando-os. Como afirma Jocelyn (1973), o verso célebre de Terêncio raramente foi interpretado de forma estrita, isto é, como ironia para com o hábito da bisbilhotice [ $\pi 0 \lambda v \pi \rho \alpha \gamma \mu o \sigma v ́ v \eta]$ e da intrusão. Michel de Montaigne, por exemplo, o interpretou como uma «confissão da fraqueza emocional e espiritual de um homem»; João de Salisbury o compreendeu como «expressão da caridade cristã». De todo modo, o verso é equivocada e costumeiramente, declamado em tom elevado e sublime.
} 
este o caso de termos como philanthropia e paideia, ambos subsumidos ao núcleo gravitacional do termo humanitas. Tal subsunção tornou-se possível porque os romanos (até mesmo os romanos helenizados, como Cícero) promoveram para si próprios um status de superioridade e autenticidade diante dos gregos. O conceito de humanitas surge então não apenas para se contrapor, mas também para expandir o escopo conceitual do mos maiorum, quer dizer, surge como lugar-tenente da autêntica romanitas do homo romanus. Trata-se de uma luta hermenêutica pelo monopólio do conceito de romanidade. O sucesso imperial de Roma só teve continuidade, certamente, porque houve tal reformulação. O pragmatismo romano instrumentalizou o conhecimento histórico e geográfico grego para racionalizar a errática política de expansão da República Imperial. Políbio e Possidônio, ao desenvolverem estudos sobre as populações da Hespanha, Parta, Celtas, persas e da Gália, o faziam como formuladores de política expansionista, não como teóricos. Tratava-se de cooperação técnica (Momigliano, 1991).

Neste aspecto, o enciclopedismo tornara-se um gênero imprescindível para a continuidade da política externa romana. O trabalho de investigação exercido por historiadores gregos como Políbio (ca. 203 a.C./120 a.C), Diodorus Siculo (ca.90 aC./ 27 a.C.) e Apiano, cada qual em seu respectivo contexto histórico-político, fora instrumentalizado pela política imperial romana como serviço de inteligência. A historiografia e a geografia tornaram-se, nas mãos do gênio romano, um desdobramento da política imperial com vistas ao mapeamento da Vrbs terrestris; como tal, tornaram-se ciências que não mais se restringiam a uma atividade livresca, contemplativa ou desinteressada; pressupunham, em razão do caráter imperial que as definia, a unidade geográfica e temporal de toda oikouménē.

Desde o advento da grei cipiônica o processo de helenização da aristocracia romana passou a ser programático, sobretudo a partir da popularidade da obra de Cícero. Ainda que tal processo já preexistisse, sobretudo na arte romana (Mommsen, 2003, vol III, p. 484-485) ${ }^{26}$, a partir do advento da grei emeliana tornara-se um movimento político-filosófico organizado e transmitido de geração a geração. E o imperativo da humanitas como formação canônica e como disposição de caráter para a ação política passou a ser um dever de ofício dos governantes, militares e diplomatas.

\footnotetext{
${ }^{26}$ Mommsen narra que «as comédias de Plauto, entre outras, mostram que o público de Roma conhecia perfeitamente as fábulas homéricas e as lendas de Hércules, e que não lhe eram desconhecidos os traços principais dos demais mitos. As escolas e o teatro provavelmente deveriam começar sua educação com a intenção de prepará-lo para que compreendesse as grandes obras poéticas da Grécia». Daí que o triunfo romano sobre os gregos tenha substituído «um idioma indisciplinado por uma língua extremamente nobre e flexível, e fez que se utilizassem metros mais variados que o monótono verso saturnino.» (Idem, p. 484-485).
} 


\section{Os primeiros registros escritos: de Cicero aos panegíricos}

O primeiro registro escrito da palavra humanitas, segundo alguns estudiosos (Birus, 1996), ocorreu na obra anônima intitulada Rhetorica ad Herennium (ca. 82 a 86 a.C), a qual, durante dez séculos foi equivocadamente atribuída a Marcus Tullius Cicero ${ }^{27}$. O texto anônimo, cuja autoria alguns imputam atualmente a Quintus Cornificius (Caplan, 1964), emprega termos como humanitate (1964, II, XVI, 24; XXI, 50), hominem (II, XVII, 26) e humanitas (IV, XVI, 23: qui victi sunt, eos homines iudicare, ut possit bellum fortitudo minuere, pacem humanitas augere $)^{28}$. Outras fontes, como o Harper's Latin Dictionary (ou Lewis and Short) apontam o emprego pioneiro do termo humanitatis, por exemplo, no discurso intitulado Pro Roscio Amerino (80 a.C.), de Cícero. Ali, o filósofo diz: «magna est vis humanitatis, multum valet communio sanguinis» (22, $63)^{29}$. Erwin Panofsky nos oferece outra versão para o emprego de humanitas, desta vez, teria origem com Cipião Emeliano, o Moço (185-129 a.C.), e seu discípulo mais conhecido, o próprio Cícero. Com ele, o vocábulo humanitas:

significava a qualidade que distingue o homem, não apenas dos animais, mas também, e tanto mais, daquele que pertence à espécie Homo sem merecer o nome de Homo humanus; do bárbaro ou do indivíduo vulgar que não tem pietas e paideia - ou seja, respeito pelos valores morais e aquela graciosa mistura de erudição e urbanidade que só podemos circunscrever com a palavra, já muito desacreditada, «cultura» (Panofsky: 1979, p. 20) ${ }^{30}$.

Importa-nos, por hora, que o emprego de termos como humanitas, humanitatis, hominem e humanus já se tornara corrente entre os romanos durante todo o primeiro século antes Cristo. Como vimos, foi na experiência política da assimilação do estoicismo heleno pelos romanos que a mitopoética da simbiose homem-terra começou a dissolver-se ${ }^{31}$, precisamente, a partir

\footnotetext{
${ }^{27}$ Desde os tempos de São Jerônimo (347-420), quando o tratado apareceu, até os estudos de Lorenzo Valla e, posteriormente, Raphael Regius, em 1491, o livro foi identificado como de autoria de Cícero. Regius foi o primeiro a desvinculá-lo da obra ciceroniana. Sabe-se desde Petrus Victorius (1582), bem como por meio de referências cruzadas com as Institutio Oratoria de Quintiliano, que o tratado provavelmente é de autoria de Cornificius (1964, p. IX-X).

${ }_{28}$ «Mas, depois de vencidos [os inimigos], vê-los como homens, de modo que possa, com bravura, pôr fim à guerra e, com humanidade, promover a paz» (Cícero [Cornificius], p. 232-233, 2005).

${ }^{29}$ «Maior é o poder da humanidade, seus laços de sangue tem uma força poderosa»

${ }^{30}$ É provável que Panofsky sustente esta tese a partir de alguma evidência extraída da Carmina Latina Epigraphica, já que os epigramas de alguns dos túmulos dos Cipiões foram preservados. Cf. Franciscvs Bvecheler e Alexander Riese, Anthologia Latina sive Poesis Latinae Supplementom (Carmina Epigraphica), Lipsiae, Tevbeneri. 1887.

${ }^{31}$ Hans Blumenberg certamente discordaria desta tese tendo em vista que para ele as teleologias antropocêntricas da relação vida-cosmos são modos de representação tardia. Segundo o autor, foi a partir de Anaxágoras que os gregos formularam uma «cosmogonia não-mítica e bem pensada» (Blumenberg, 1987, p. 10). O problema que temos que enfrentar, neste aspecto, não diz respeito ao pioneirismo filosófico, mas à assimilação desta cosmogonia pelo governo da polis.
} 
do processo de helenização do vocabulário imperial romano, bem como a partir da experiência das batalhas de aniquilação e das guerras civis ${ }^{32}$. O impacto militar e diplomático causado pela destruição das cidades de Corinto (146 a.C.), da Numância (133 a.C.) e de Cartago (146 a.C) fora de tal intensidade que alguns sectos da elite romana passaram a reivindicar uma nova filosofia prática para a expansão do Império, uma filosofia que conciliasse a expansão política sem incorrer no risco da fragmentação do Império. Até então, os líderes políticos da República Imperial - Cipião Africano em Zama e na Ibéria Ilúrgia (206 a.C), Emílio Paulo em Pidna (168 a.C.) e Epiro (167 a.C.), Cipião Emeliano em Cartago e Numância, Lúcio Múmio Acaico em Corinto - entendiam que o desfecho natural da guerra deveria ser o excídio, isto é, a aniquilação física e moral do inimigo. Em substituição a tal ímpeto beligerante e aniquilador, expresso na sentença proferida por Catão-o-Velho - ceterum censeo Carthaginem esse delendam -, propugnava-se o princípio estoico da oikeiôsis, isto é, da apropriação e familiarização do inimigo como membro da comunidade política romana ${ }^{33}$. Para tanto, virtudes cardinais como clemência

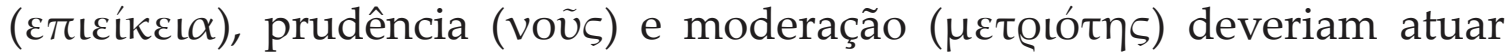
como lugares-tenentes da violência. A insistência da filosofia política e da retórica romana no que diz respeito à busca pela humanitas - definida como amicitia, philantropia, sapientia, elegantiae, pietas, utilitatis, mansuetudo, clementia e facilitas - ao longo deste último século pré-cristão explica-se, também, pela necessidade imposta aos governantes do Império quanto a apaziguar os ânimos dos cidadãos numa época marcada por contínuas guerras civis (Frighetto, 2004). Tais governantes deveriam prezar pelo equilíbrio e urbanidade em suas decisões no que diz respeito aos povos da orbe romanorum, tanto quanto no que diz respeito às questões de política interna. A origem da humanitas, portanto, estaria nos códigos da diplomacia da baixa República Romana, caracterizados por suas recomendações de mansidão e contemporização no exercício do poder sobre os territórios e povos subjugados. Estaria, também, nas recomendações de mansidão e afabilidade entre governantes e cidadãos no que diz respeito às questões de política interna romana (basta nos lembrarmos do caso de Caio Verres, imortalizado por Cícero).

\footnotetext{
${ }^{32}$ A chamada crise da República Romana (134 - 27 a.C.), conhecida por culminar na transformação da República em Império Romano foi marcada por diversas guerras civis, dentre elas: a Última Guerra Civil das Repúblicas Romanas (32 - 30 a.C.), a Segunda Guerra Civil da República Romana (49- 45 a.C.), a Terceira Guerra Civil da República Romana (43-42 a.C.). A crise se estende, segundo alguns historiadores, da primeira guerra Servil (134 a.C.), passando pelas guerras samnitas (82 a.C.), a Terceira Guerra Servil liderada por Spartacus (73-71 a.C.) até a já referida Última Guerra Civil.

${ }^{33}$ Cícero assim define a oikeiôsis no De Finibus: [...] «provém da natureza a tendência para a relacionação dos homens entre si, o que faz com que um homem na presença de outro sinta, só pelo facto de ser homem, que não está perante um estranho. [...] Somos, de facto, naturalmente aptos para a formação de grupos, de assembleias, de cidades.» (Cícero, XIX, 63-64, p. 402-403).
} 
A metáfora da dissolução de um símbolo mitopoético, como o descrevemos aqui, designa o processo de redefinição e politização de certos conteúdos semânticos segundo os fins práticos preestabelecidos por uma elite cultural e política. A designação do «humano», durante os séculos III, II e I da era pré-cristã perdera seu substrato mitopoético e passara a admitir um conteúdo semântico aberto, volátil e politicamente determinado. O conceito fora adredemente deslocado de seu terreno pátrio, mítico e ontológico, para restabelecer-se sobre um território abstrato, impreciso, cosmopolita, juridicamente volátil e filosoficamente doutrinário. Este movimento começa com o estoicismo heleno e se realiza politicamente na Baixa República Romana. O que explica tal processo de dissolução e deslocamento semântico, isto é, o caráter transitivo do conceito de humanitas, é sua relação estreita com os conceitos de kosmópolis e oikeiôsis. Por outro lado, para compreendermos o caráter inovador de tal conceito devemos, assim como fizemos anteriormente, contrapô-lo ao imperativo tradicional republicano do mos maiorum.

O gênio romano não foi o responsável por produzir a síntese conceitual e simbólica para esta nova experiência política (da unidade humana como oikouménē), mas foi o responsável por tornar o conceito do homem um móbil política e juridicamente determinado conforme as ambições do Império. É a consciência de uma comunidade universal de todos os homens que permitirá aos romanos nomeá-la por humanitas, no sentido de uma grandeza política «supranacional». Por outro lado, com a palavra homo ${ }^{34}$, os romanos romperam com o sentido pátrio-natural que encontramos nos radicais homólogos indo-europeus, tendo em vista que o termo designava alguém sem qualificação ou personalidade jurídica. Daí que a concessão de cidadania pelo Direito Público Romano se fundasse no princípio da patria iuris ou patria civitas, isto é, no princípio do pertencimento juridicamente concedido mediante o qual a cidadania poderia ser outorgada aos cidadãos nascidos ou não na circunscrição da cidade de Roma ${ }^{35}$. Em contraposição, os gregos, por exemplo, reconheciam tão somente a filiação

\footnotetext{
${ }^{34}$ Acerca da origem teatral e dramatúrgica do conceito de humanitas, tal como enfatiza Ahn (2009), Hannah Arendt assinala que «os romanos foram os primeiros a usar o nome [persona, i.e., máscara] em um sentido metafórico; na lei romana, persona era alguém que possuía direitos civis, muito diferente da palavra homo, que denotava alguém que não passava de um membro da espécie humana, sem dúvida distinto de um animal, mas sem qualquer qualificação ou distinção específica, de tal forma que a palavra homo, assim como a palavra grega anthropos, era amiúde usada em sentido pejorativo, designando pessoas desprotegidas da lei.» (Arendt, p. 176, 2006).

${ }^{35}$ Veja-se, por exemplo, o caso do poeta grego Archia. Ele reivindicava a cidadania romana, não só por residir em Roma, mas por ter cantado em verso as glórias militares daquela República. Alegava-se, contra o bardo, que ele escrevia em grego. Cícero advogou em sua defesa no discurso intitulado Pro A. Licinio Archia Poeta Oratio (62 a.C; 1986). O caso mais conhecido, contudo, é o de Paulo de Tarso, cidadão romano que, segundo Jerônimo, nasceu em Giscalis, na Judeia.
} 
dada pelo nascimento pátrio, isto é, a filiação concedida pelo enraizamento térreo-natalício, a patria loci3 ${ }^{36}$.

De todo modo, encontramos ocorrências de humanitas posteriormente nos escritos de Sêneca (4 a.C. a 65 d.C.), Quintiliano (35 d.C. a 95 d.C.), Tácito (55 d.C. a 120 d.C.), Tito Lívio (59 a.C. a 17 d.C.), Plínio, o jovem (ca. 61-62 d.C. a 114 d.C.) e Aulo Gélio (125 a.C. a 180 d.C.) $)^{37}$. Humanitas designava, neste primeiro século da era imperial augustana, a formação ideal do orador (paideia), cujas virtudes de caráter necessárias para o exercício da vita activa (a vida pública dedicada à política) adviriam do estudo da bonae litterae, isto é, adviriam da res humaniores e da studia humanitatis. Daí que alguns filólogos convirjam quanto à origem da palavra, que, a

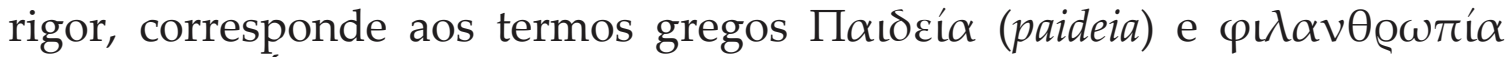
(filantropia). É o que nos disse Aulo Gélio ao assinalar que:

Os que praticaram as palavras latinas, e os que destas se serviriam com probidade, não quiseram humanitas ser isso que o vulgo estima e que pelos gregos é dito $\varphi \iota \lambda \alpha v \theta \varrho \omega \pi i ́ \alpha$ e significa certa afabilidade e benevolência para com todos os homens indistintamente, mas denominaram humanitas mais

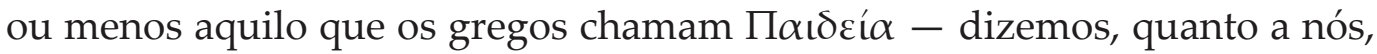
instrução e formação para as boas artes. [...] Com efeito, dessa ciência o cuidado e o ensinamento foram dados só ao homem, dentre todos os seres animados, e por isso ela foi denominada humanidade (humanitas). Assim, então terem usado essa palavra os antigos, e principalmente Marco Varrão e Marco Túlio, quase todos os livros declaram (Aulo Gélio, Noites Áticas; $13,17,1 ; 2010$, p. 445).

As qualidades filantrópicas, paidêuticas e relativas à afabilidade no trato como o outro, como podemos perceber neste excerto de Aulo Gélio, foram unificadas num único termo, humanitas, e seus correlatos. Tratava-se, desde o Círculo de Cipião Emiliano, de um código de conduta endereçado enfaticamente aos governantes responsáveis pela política externa e interna do Império Romano. Daí que a amarga experiência da tirania, como fora o caso do reinado de Nero, levasse filósofos como Sêneca a distinguir misericórdia e clemência de modo que esta, associada à humanitas, fosse concebida como uma virtude dos bons governantes, ainda que a misericórdia jamais o fosse ${ }^{38}$.

\footnotetext{
${ }^{36}$ Cf. Fernando Catroga. Pátria e Nação, 2001.

${ }^{37}$ As ocorrências dos termos humanitas, e humanus podem ser verificadas com precisão no sítio Perseus. Cf. http://www.perseus.tufts.edu/hopper/. Cf. ainda: https://translate.enacademic. com $/ \mathrm{h} \% \mathrm{C} 5 \% \mathrm{ABm} \% \mathrm{C} 4 \% 81$ nit $\% \mathrm{C} 4 \% 81 \mathrm{~s} / \mathrm{la} / \mathrm{xx} /$

${ }^{38}$ Sêneca compara misericórdia e clemência na seguinte passagem: «Nesta altura é pertinente investigar o que é misericórdia [misericordia], pois a maioria dos homens louva-a como virtude e chamam misericordioso [misericors] ao homem bom. E ela é um defeito de alma. Devemos evitar cada uma das atitudes que estão colocadas nas margens da severidade [severitas] e nas margens da clemência [clementia]. Pois com a aparência de severidade [severitas] incidimos na crueldade, com a aparência da clemência [clementia], na misericórdia [misericordia] [...] Portanto, do mesmo modo como a religião honra os deuses, a superstição os ultraja, assim
} 
Cícero empregou abundantemente as variações do termo em tratados, cartas e discursos como, por exemplo, no registro do termo encontrado no discurso intitulado In Verrem (70 a.C.), onde se lê: partitione ornatos non plus victoria Marcelli populo Romano adpetivit quam humanitas Syracusanis reservavit ${ }^{39}$. Em geral, Cícero empregava humanitas em contraposição a feritas ou animalitas, porém, a palavra admitia três significados recorrentes ${ }^{40}:(1)$ enfatizava atributos morais humanos como o senso de bondade, filantropia, equilíbrio, honra, civilidade, humor, gentileza, cortesia, urbanidade e polidez, os quais equivaleriam a sinônimos como mansuetudo, clementia e facilitas, todos atributos próprios aos cidadãos no exercício da vita activa, sobretudo governantes. (2) referia-se ao humanum genus, como se vê em passagens do De Officiis, nas quais o Arpinate acentuava a singularidade do gênero humano, não em sentido biológico, como é comum ao imaginário moderno, mas no sentido de uma comunidade universal de pertença natural cujos vínculos se estabelecem pela indústria humana e seus atributos da razão e da linguagem (I, 50-51); tais atributos devem conformar as leis e o direito civil às leis da comunhão natural. Um terceiro significado (3) encontrado, por exemplo, nas Orações, refere-se ao cultivo dos estudos, à boa educação liberal, à elegância das maneiras, ao uso bem-educado da linguagem e ao refinamento espiritual. Seriam sinônimos desta última humanitas termos como doctrina, litterae, politioris e eruditio, como podemos ver na passagem das Orações: homo non communium litterarum et politioris humanitatis expers $(2,16,72$, p. 250, 1967).

Estes três sentidos, como assinala Birus, compõem o conteúdo substantivo do conceito do humano, e não simplesmente o conteúdo negativo, isto é, a negação de feritas ou animalitas, como assinalou Heidegger (1946) ao citar Cícero. Fato é que tais atributos substantivos não eram concebidos como universais, mas restringiam-se aos cidadãos do Império Romano, membros da patria civitatis, quer dizer, restringiam-se àqueles que pertenciam à ordem social, política, educacional e moral romana. Como afirmara Cícero no tratado sobre a República: «appellari ceteros homines, esse solos eos, qui essent politi propriis humanitatis artibus» (De re publica I, 28) ${ }^{41}$.

todo homem de bem oferecerá clemência e mansidão, e evitará a misericórdia [misericordia], porque é falha de um espírito pusilânime sucumbir à vista dos infortúnios alheios. Assim, esta atitude é muito comum entre os que estão nas piores condições. Existem velhas e mulherzinhas que se comovem com as lágrimas dos maiores criminosos e que, caso fosse permitido, lhes arrombariam a porta do cárcere. A misericórdia [misericordia] não observa a causa do castigo, mas o infortúnio do criminoso. A clemência se aproxima da razão». [Sêneca, Tratado Sobre a Clemência, 2013, II, 5.1, p. 44.]

39 «Nesta divisão dos ornamentos, a vitória de Marcellus não ambicionava mais ao povo romano do que a humanidade por ele reservada aos siracusanos» $(2,4,121)$.

${ }^{40}$ Oxford Latin Dictionary, 1968, p. 809.

${ }^{41}$ «persuadido de que, dos restantes que são chamados homens, só o são os que se ilustram com as artes próprias da humanidade» (Cícero, Res, 2008, p. 91). 
Todos aqueles que não eram submetidos à educação romana, à studia humanitatis, eram considerados bárbaros, isto é, animais incivis que só eram capazes de dizer «ba, ba, ba, ba», onomatopeia que deu origem a

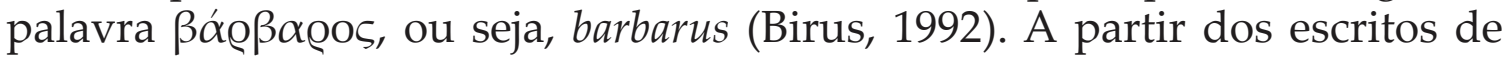
Aulus Cornelius Gellius em Noctes Atticae (2011), esta ênfase sobre o caráter paidêutico da educação romana como elemento civilizador e registro de pertença ao Império tornara-se mais clara. Mais do que o lugar de nascimento, é a formação canônica por meio das boas leituras que concederá ao cidadão romano, entre outros requisitos, os «direitos» políticos de pertença à patria iuris civitatis, isto é, os «direitos» e deveres de cidadão do Império.

Há ainda o exemplo do gramático Marcus Terentius Varro, o Varrão (11627 a.C.). Para ele, a humanitas definir-se-ia pela dupla finalidade da utilitas e da elegantia (De Lingua Latina, VIII, 3; Frighetto, 2004). Esta última, estreitamente relacionada aos homens dotados de humanitas, isto é, os cultivados, amantes da beleza e da cortesia nas relações sociais e amicais ${ }^{42}$. Em razão dessa proximidade entre elegância, fineza e cortesia, Cícero, em De Amicitia (II, 7) enfatizava a sapientia como a mais importante dentre as virtudes humanas. Tal Sabedoria revelar-se-ia no cultivo das amizades, as quais evidenciariam a humanitas, isto é, a polidez, a fineza e a civilidade do indivíduo nas relações públicas. Por amizade, o célebre orador não estaria a designar o caráter privado e subjetivo das relações e dos laços afetivos entre duas pessoas. Contrariamente, a amiticia designava as ligações objetivas, articuladas sob as demandas práticas oriundas das relações políticas entre os cidadãos da cidade de Roma. Nesta lógica, o caráter público e objetivo das amizades entre os homens dotados de humanitas exigiria que os laços de compromisso, assistência recíproca e boa-fé estivessem fundados na virtude da lealdade (fides). A amizade estaria, assim, não apenas vinculada aos compromissos parentais ou privados, mas se afirmaria, preferencialmente, nos vínculos de interesse, na dependência mútua, no patronato (beneficium) e na lealdade política (Hellegouarc'h, 1972).

Daí surgiria, aproximadamente um século depois, no Panegyricus Traiano Dictus (100 d.C.), de Plínio, o Jovem, o ideal do optimus princeps, no qual o orador e político agradece sua nomeação de consul suffectus ao Imperador Trajano. Foi a partir desta obra, em verdade um gratiarum actio, que adveio o sentido Alto-imperial da humanitas como um conjunto de virtudes necessárias aos príncipes e imperatores. Como sabemos, Plínio foi o responsável por acrescer o agnome optimus ao Imperador Trajano, assim como Júlio César fora chamado Juppiter Julius. Não se tratava de um mero epíteto, mas de um atributo a um quase semideus cujo reconhecimento era público

\footnotetext{
${ }^{42}$ M. Terentii, Varronis. De Lingua Latina, Liber VIII, XVI (Trad. Maria Lucilia Ruy): «Pois caso alguém considere existir um duplo propósito para que se deva alcançar aquelas metas da natureza acerca do uso - utilidade e elegância - como não nos desejamos vestir apenas para evitar o frio, mas também para parecer convenientemente vestidos; [...] um é suficiente ao homem, o outro, à erudição.»
} 
e oficial (Frighetto, 2012, p.39). Tal agnome resumiria as virtudes e qualidades morais do Imperador de forma tal que a soberania pessoal adviria não de suas riquezas ou de seu poder, mas do caráter irrepreensível de suas virtudes no que diz respeito ao exercício do poder. O agnome ótimo era um epíteto de Júpiter. As virtudes de Trajano, aos olhos de Plínio eram moderatio, mansuetudo, clementia, pietas, iustitia, civilitas, abstinentia, continentia, frugalitas, facilitas, veritas, simplicitas e humanitas. Não se tratava de encarnar o poder na figura de Trajano, mas de enfatizar a humanitas do Imperador a um só tempo como virtus, isto é, como habilidade militar e política no exercício do poder, mas também como mos maiorum, isto é, observância e respeito aos costumes republicanos tradicionais, a despeito da vigência de um regime monárquico, autocrático. A humanitas do optimus princeps se fazia exercer como virtude pública (servitium, deferencia, iustitia), como moderação estoica e como moral pessoal.

Do mesmo modo, Eusébio de Cesareia, no panegírico Vita Constantini (337 d.C), referia-se ao Imperador como voce divina e imperator aeterne, reiterando a imagem de Constantino como um enviado de Deus cuja missão era acabar com a perseguição aos cristãos no Império. Eusébio, para dar mais vivacidade a esta visão deificada do Imperador, aproximava-o da imagem de Moisés ${ }^{43}$. Sabemos que o culto do Imperador - a apoteose - não era um hábito da tradição republicana, fora introduzido em Roma por influência dos cerimoniais políticos orientais ${ }^{44}$. É esta influência que converteu do conceito de humanitas numa designação de virtudes imperiais. Portanto, no período do Alto-Império Romano (44-31 a.C. à 284 d.C.), o termo $h u$ manitas passou a relacionar-se diretamente com as qualidades pessoais e públicas necessárias aos imperatores, governadores, cônsules e magistrados para o exercício do poder imperial.

\section{Conclusão}

Desde a origem, o conceito de humanitas e seus correlatos designam um conteúdo semântico aberto e receptivo a qualquer significado político ou jurídico a ele imposto. A volatilidade do termo, enquanto caractere originário provocou oscilações que passaram a obedecer à vontade régio-imperial, fosse essa expressão da voga estoico-romana, fosse expressão da verdade

\footnotetext{
${ }^{43}$ Esta mesma imagem divinizada de Constantino se vê no De Mortibus Persecutorum (314315 ca.) de Lactâncio.

${ }^{44}$ Como é consabido, Júlio César adotou o culto da personalidade à moda egípcia para unificar a violência inconstitucional militar com o apoio popular. Fora esta a solução do cesarismo para a expansão política sem a consequente fragmentação do Império. Alguns imperadores promoviam o culto imperial, tais como Calígula, Nero e Domiciano; outros, mais moderados e constrangidos, como Tibério, Cláudio e Vespasiano, recusavam as adorações, oferendas sacrificiais e fumegações próprias à apoteose.
} 
cristã. O conteúdo semântico permanentemente aberto, indeterminado e flutuante conduziu os impérios da christianitas católica e da romanitas pagã, no contexto político-teológico da Antiguidade Tardia, a uma digladiação pelo monopólio da autoridade hermenêutica no que diz respeito à definição do conceito. Quer dizer, por humanitas, Santo Isidoro de Sevilha, no século VII, designava o conjunto das virtudes cristãs nicenas próprias ao caráter do Imperador; o louvor de tais virtudes se dava em contraposição às heresias arianas, pagãs e tirânicas dos bárbaros invasores. Passou a haver um processo recíproco de romanização da cristandade associado a uma cristianização da romanidade.

A cristianização da humanitas tornara-se evidente à medida que se consolidava o progressivo monopólio eclesial enquanto autoridade última definidora do conteúdo semântico do conceito. Paulatinamente o episcopado ariano e os reis bárbaros recém-convertidos ao catolicismo passaram a aceitar a tese nicena da heresia. O exemplo de Sisebuto de Toledo explica esta reviravolta cristã no que diz respeito à definição do conceito. Em Vita vel Passio Sancti Desiderii, vê-se uma inversão das posições da tradição panegírica imperial: agora é o rei quem redige o elogio à vida de um santo, São Desidério, e não o santo, como o fazia Sidônio Apolinário, quem expõe em panegírico as virtudes do rei (Frighetto, 2004). Numa palavra, a tradição panegírica convertera-se em tradição hagiográfica ${ }^{45}$ visigótico-merovíngia. As narrativas das vidas dos santos e os panegíricos tornaram-se gêneros da propaganda político-religiosa de um império desintegrado e passaram a visar à audiência de um grande público, não apenas os imperadores. O objetivo passou a ser a conversão de novos cristãos, além da parênese edificante que se fundava na exemplaridade das virtudes e na grandeza dos milagres e martírios. Assim, o conceito de humanitas fora, durante o período das invasões bárbaras tardo-antigas até o renascimento carolíngio, progressivamente cristianizado a tal ponto que a virtude da humanidade se tornara sinônimo de cristandade.

\section{Referências bibliográficas}

AGAMBEN. O Reino e a Glória: Uma genealogia teológica da economia e do governo. Boitempo Editorial, 2015.

AGOSTI, Hector P. Condições Atuais do Humanismo. Paz e Terra. Rio de Janeiro, 1970.

AHN, Jaewon. "Cicero's humanitas in forensic Speech: focusing on Pro Roscio Amerino". Classica-Revista Brasileira de Estudos Clássicos, v. 22, n. 2, p. 216-228, 2009.

AHN, Jaewon. "On Roman Humanitas: Is It a Universal Idea or an Imperial One?". Horizons: Seoul Journal of Humanities, v. 7, n. 2, 2016.

${ }^{45}$ Emprego aqui anacronicamente a palavra hagiografia. Como sabemos, trata-se de uma disciplina cuja sistemática data do século XVII. Cf. Delehaye, Lês Légends Hagiographique, 1973. 
ALIGHIERI, Dante. A Divina Comédia. (trad. Cristiano Martins). Itatiaia/Edusp, São Paulo, 1979.

ARBEA, Antonio. "El concepto de humanitas en el Pro Archia de Cicerón". Onomazein, n. 7, p. 393-400, 2002.

ARENDT, H. A Condição Humana. Rio de Janeiro. Forense Universitária, 2011.

ARENDT, H. A Dignidade da Política. Rio de Janeiro: Relume-Dumará, 2006.

AUSTIN, A.E. Scipio Aemilianus. Oxford University. Claredon Press. 1967.

BADALANOVA GELLER, F. (slavonic apocalypse of) enoch 2: text and context. 2010.

BEEKES, R. S. P.; VAN BEEK, L. Etymological dictionary of Greek. Leiden: Brill, 2010.

BIRUS, Hendrik. “The Archeology of 'humanism'”. Surfaces: Revue Électronique, Vol. VI, 1996. Université de Montréal.

BLUMENBERG, Hans. The genesis of the Copernican world. (trans. R.M. Wallace). MIT Press, 1987.

BOMBASSARO, L. C.; PAVIANI, J.; ZUGNO, P. L. As fontes do humanismo latino. v. 1. Porto Alegre: Edipucrs, 2003.

BROWN, M. R. A Study of the Scipionic Circle. The Classical Review, Vol. 49, Issue 01, February 1935.

BRUGMANN, Karl; DELBRÜCK, Berthold. Grundriss der vergleichenden Grammatik der indogermanischen Sprachen, v. 5, 1886.

BUBER, Martin. El Humanismo Hebreo y Nuestro Tiempo. Ediciones Porteñas. Buenos Ayres, 1978.

BUCK, C. D. A dictionary of selected synonyms in the principal Indo-European languages. University of Chicago Press, 1988.

BUDGE, E. A. Wallis. O Livro Egípcio dos Mortos. Editora Pensamento. São Paulo, 1985.

BURKERT, Walter. Religião Grega na Época Clássica e Arcaica. Calouste Gulbenkian, Lisboa, 1993.

BVECHELER, Franciscvs e RIESE, Alexander. Anthologia Latina sive Poesis Latinae Supplementom (Carmina Epigraphica), Lipsiae, Tevbeneri. 1887.

CAMPANA, A. «The Origin of the Word Humanist». Journal of the Warburg and Courtauld Institutes 9:60-73, 1946.

CARDIGNI, J. El Comentario como género tardoantiguo: Commentarii in Somnium Scipionis de Macrobio. Editorial de la Faculdad de Filosofia y Letras/ Universidad de Buenos Aires. Buenos Aires, 2013.

CESAREA, Eusebio de. Vida de Constantino. Madrid: Editorial Gredos, 1994.

CHRISTES, Johannes. Cicero und der römische Humanismus. Humboldt-Universität zu Berlin, Philosophische Fakultät II, Institut für Klassische Philologie, 1995.

CÍCERO [CORNIFICIUS], Retórica a Herênio, Hedra, São Paulo, 2005.

CICERO III. De Oratore I, II. (Translated by E.W. Sutton), William Heinemann, Harvard University Press, 1962. 
CÍCERO, M. T. Da República. [Trad. Amador Cisneiros]. pp.145-188. Os Pensadores. São Paulo. Abril Cultural. 1973.

CÍCERO, M. T. Dos Deveres: De Officiis, Lisboa, Edições 70, 2000.

CICERO, M. T. Pro Archia Poeta Oratio. Bolchazy-Carducci, 2006.

CÍCERO, M. T. Do sumo bem e do sumo mal (de finibus). Martins Fontes, 2005.

CICERO, M. T. The Orations of Marcus Tullius Cicero, literally translated by C. D. Yonge. London. George Bell \& Sons. 1903.

CÍCERO, M.T. Da Amizade. Martins Fontes, São Paulo, 2012.

CÍCERO, M.T. Textos Filosóficos. Fundação Calouste Gulbenkian, Lisboa, 2012.

CICERO, M.T. The Verrine Orations, Vol. 2. Trad. L.H.G. Greenwood. Harvard University Press, 1935.

CICERO, Pro Roscio Amerino, (Editor: E.H. Donkin), Bristol Classical, 1991.

CÍCERO. Tratado da República. [Trad.de Francisco de Oliveira]. Círculo de Leitores e Temas e Debates, Lisboa, 2008.

DE ALMEIDA, C. R. R. “Prolegômenos à antropologia filosófica: histórico de um programa de pesquisa". Princípios: Revista de Filosofia (UFRN), v. 26, n. 49, p. 45-82, 2019.

DELEHAYE, H. Les légendes hagiographiques. Bureaux de la Société des Bollandistes, 1906.

DÍAZ, Pedro Rafael et al. Três biografias latino medievales de San Desidério de Viena (traduccion y notas). Fortunatae: Revista Canaria de Filología, Cultura y Humanidades Clásicas, n. 5, 1993.

DUMONT, J.-P. Elementos de História da Filosofia Antiga. EdUNB, Brasília, 2004.

EIBL-EIBESFELDT, I. Human Ethology. Routledge, 2017.

ERNOUT, Alfred; MEILLET, Antoine. Dictionnaire étymologique de la langue latine. Histoire des mots, 1951.

ETCHEVERry, A. O Conflito Actual dos Humanismos. Porto, Tavares Martins, 1975.

FAVAREAU, D. Essential readings in biosemiotics: Anthology and commentary. Springer Science \& Business Media, 2010.

FÍLON DE ALEXANDRIA. "De Joseph", in ARNIM, H. VON. Stoicorum Veterum Fragmenta, Vol. II. Stuttgart: Teubner, 1978-1979.

FOUCAULT, M. “O homem está morto?”. Arts et Loisirs, n. 38, 15-21, junho de 1966, p. 8-9. FRIGHETTO, R. "Da antigüidade clássica à idade média: a idéia da Humanitas na antigüidade tardia ocidental". Temas medievales, n. 12, p. 147-164, 2004.

FRIGHETTO, R. A antiguidade tardia: Roma e as monarquias romano-bárbaras numa época de transformações (Séculos II-VIII). Juruá, 2012.

FROMM, E. O Conceito Marxista do Homem. Zahar Editores. Rio de Janeiro, 1970. GALLETIER, Édouard (Ed.). Panégyriques latins (I-V). Tome I. Paris. Belles Lettres, 1949. 
GARAUDY, R. Humanismo Marxista. Cinco Ensayos Polémicos. Ediciones Horizonte. Buenos Aires, 1959.

GEHLEN, Arnold. Antropología Filosófica. Del Encuentro y Descubrimiento del Hombre por sí mesmo. Ediciones Paidos. Barcelona-Buenos Aires-Mexico, 1993.

GÉLIO, Aulo. Noites áticas: Noctes atticae. Tradução e notas: José Rodrigues Seabra Filho. Introdução: Bruno Fregni Bassetto. Londrina: Eduel, 2010.

GESENIUS, Wilhelm; TREGELLES, Samuel Prideaux. Gesenius's Hebrew and Chaldee Lexicon to the Old Testament Scriptures. London: S. Bagster, 1859.

GIRÓN, María Angeles Navarro. La carne de Cristo: el misterio eucaristico a la luz de la controversia entre Pascasio Radberto, Ratramno, Rabano Mauro y Godescalco. Univ Pontifica Comillas, 1989.

GROTHUYSEN, B. Antropologia Filosófica. (2aed). Editorial Presença. Lisboa, 1988. HEIDEGGER, M. Carta sobre o Humanismo.[Trad. Pinharanda Gomes] Guimarães Editores. Lisboa, 1987.

HELLEGOUARC, H. J. Le vocabulaire latin des relations et des partis politiques sous la République. Les Belles Lettres, Paris, 1972.

JASPERS, Karl. Origen y meta de la historia. Alianza, 1968.

JOCELYN, H. D. "Homo sum: humani nil a me alienum puto", Antichthon, vol. 7, p. 14-46, 1973.

KLIBANSKY, Raymond; PANOFSKY, Erwin; SAXL, Fritz. Saturn and melancholy: Studies in the history of natural philosophy, religion, and art. McGill-Queen's PressMQUP, 2019.

LEWIS, Charlton Thomas; SHORT, Charles. Harpers' Latin dictionary. A New Latin Dictionary Founded on the Translation of Freund's Latin-German Lexicon, edited by E.A. Andrews, 1879.

LIDELL HART, B.H. Scipio Africanus. Greater Than Napoleon. Da Capo Press. Sd.

MACROBIUS. Saturnalia. Books 1-2. Kaster, R. (trad.). Harvard, Loeb Classical Library, 2011.

MARCEL, Gabriel. Existentialisme Chrétien. (Présentation de Étienne Gilson). Librairie Plon. Paris, 1947.

MARÍAS, Julian. O Tema do Homem. Livraria Duas Cidades. São Paulo, 1975.

MARITAIN, J. Humanismo integral: uma visão nova da ordem cristã. Cia Editora Nacional, 1945.

MARROU, H. I. História da Educação na Antiguidade. Epu, 1966.

MCCURDY, J. Frederic; KOHLER, Kaufmann; GOTTHEIL, Richard. "Adam" in Jewish Encyclopedia. Vol.1, p. 173-179, 1906.

MEZZAROBA, Orides. Humanismo político: presença humanista no transverso do pensamento político. Fundação Boiteux, 2008.

MOMIGLIANO, A. Os Limites da helenização a interação cultural das civilizações grega, romana, celtica, judaica e persa. J. Zahar, 1991. 
MOMMSEN, T. Historia de Roma. 4 Volumes. Turner, 2003.

NAVARRO ANTOLÍN, F. Comentario al Sueño de Escipión de Cicerón. Madrid, Gredos.

NIETHAMMER, F.I. Philanthropinismus-Huamanismus, Texte zur Schulreform, bearb, v. W. Hillebrecht, Weinheim-Berlin-Bassel, 1968, $79 ß 445$ (Kleine Pädagogische Texte 29).

NOGARE, Pedro Dalle. Humanismos e Anti-Humanismos. Introdução à Antropologia Filosófica. (10aed.). Vozes. Petrópolis, 1985.

OLIVEIRA, Odete Maria de. Conceito de homem: mais humanista, mais transpessoal. Ed. UNIJUI, 2006.

PEREIRA, Maria Helena da Rocha. Estudos de história da cultura clássica: cultura romana. Lisboa: Calouste Gulbenkian, v. 2, 2002.

PEREIRA, Maria Helena da Rocha. Estudos de história da cultura clássica. Lisboa, Fundação Calouste Gulbenkian, vol 1, Cultura Grega, 2006.

PLINIO EL JOVEN. Panegírico de Trajano. Traducción, Introducción y Notas por Álvaro D’Ors. Instituto de Estudios Políticos, 1955.

PLUTARCO. Valério Publícola e o Advento da República Romana. Editorial Inquérito, Lisboa, 1941.

POKORNY, Julius. Proto-Indo-European Etymological Dictionary. A Revised Edition of Julius Pokorny's Indogermanisches Etymologisches Wörterbuch. Published on the Internet: Indo-European Language Revival Association, 1959.

PULEDDA, Salvatore. Interpretaciones Del humanismo. Mimeo, 1996.

QUINTILIANO, Marco Fábio. Instituição oratória (Tomo I). Trad. Bruno Fregni Bassetto. Campinas, SP: Editora da Unicamp, 2015.

RADICE, Roberto. Estoicismo. Idéias e Letras, São Paulo, 2013.

RICOEUR, P. O conflito das interpretações: ensaios de hermenêutica. Tradução de Hilton Japiassu. Rio de Janeiro: Imago, 1978.

SARTRE, J.-P. O Existencialismo é um Humanismo. Trad. Vergílio Ferreira. Editorial Presença. Lisboa, 1970.

SCHELER, Max. Do eterno no Homem. Vozes, 2015.

SCHENK, Arno. De Isidori Hispalensis de natura rerum libelli fontibus. G. Nevenhahni, 1909.

SCHWARTZ, Jeffrey H.; TATTERSALL, Ian. The human fossil record, craniodental morphology of genus Homo (Africa and Asia). John Wiley \& Sons, 2005.

SEBASTIANI, BRENO BATTISTIN. O Aniquilamento de Cartago e Numância. Topoi, v. 14, n. 26, jan./jul. 2013, p. 132-142 I Rio de Janeiro.

SÊNECA, L.A. Tratado sobre a clemência. Petrópolis-RJ: Vozes, 1990.

SÉNECA, Lúcio Aneu. Cartas a Lucílio. Lisboa: Fundação Calouste Gulbenkian, 1991.

SEVILLA, San Isidoro de. Etimologías. BAC, Madrid, 2009.

SNELL, Bruno. A descoberta do espirito: as origens do pensamento europeu na Grécia. Lisboa: Edições 70, 2003. 
SOUSA, Rogério Ferreira. "Coração". in Luís Manuel de Araújo. Dicionário do Antigo Egipto. Editorial Caminho, Lisboa, 2001.

STEIN, Ernildo. Nas proximidades da antropologia: ensaios e conferências filosóficas. Ijuí: Unijuí, 2003.

STIER, F. «Adão» in FRIES, Heinrich (org.). Dicionário de Teologia. Conceitos Fundamentais da Teologia Atual. (Vols. 1). São Paulo, Edições Loyola, 1983.

STRASBURGER, H. «Der Scipionenkreis», Hermes, 94, 60-72, 1966.

SUETONII, G. TRANQUILLI. De vita Caesarum libros VIII et De grammaticis et rhetoribus librum, ed. Robert A. Kaster, Oxford, 2016.

SUETONIUS. De grammaticis et rhetoribus. Translated by J.C. Rolfe in two volumes. London: The Loeb Classical Library, 1979.

SYME, Ronald. The Roman Revolution. Oxford, Claredon Press, 1939.

TERÊNCIO. O homem que se puniu a si mesmo. Introdução, versão do latim e notas de Walter de Sousa Medeiros. Coimbra, 1992.

TERRA, João Evangelista Martins. O Deus dos indo-europeus: Zeus e a proto-religião dos indo-europeus. Edições Loyola, 1999.

VALPY, F.E.J. An Etymological Dictionary of the Latin Language, London, Boldwin and co. / Longman and co. / G.B. Whittaker, 1828.

VARRÓN, Marco Terencio. La lengua latina. Madrid, Gredos, 1998.

VOEGELIN, Eric. Ordem e história: era ecumênica. São Paulo: Loyola, v. 4, 2010.

ZETZEL, J.G.E. Cicero and the Scipionic Circle. Harvard Studies in Classical Philology, 1972.

Endereço do Autor:

R. Ricardo Pearce Brito, 4918 - Ed. França - Apto. 304

Bairro Campestre

64053-520 Teresina - PI

ranieriribas@yahoo.com.br 